\title{
PTHrP Induces STAT5 Activation, Secretory Differentiation and Mammary Tumor Progression
}

Diego Y. Grinman ${ }^{1 *}$, Kata Boras-Granic ${ }^{1 *}$, Farzin M. Takyar ${ }^{2 *}$, Pamela Dann ${ }^{1}$, Julie R. Hens $^{1}$, Christina Marmol ${ }^{3}$, Jongwon Lee ${ }^{4}$, Jungmin Choi ${ }^{5,6}$, Lewis A. Chodosh ${ }^{7}$, Martin E. Garcia Sola ${ }^{8}$, and John J. Wysolmerski ${ }^{1}$

1. Section of Endocrinology, Department of Internal Medicine, Yale School of Medicine, New Haven, CT, US.

2. Research Institute for Endocrine Sciences, Shahid Beheshti University of Medical Sciences, Tehran, Iran

3. PrimeCare Health, 3924 W Fullerton Ave, Chicago, IL 60647

4. Brain Korea 21 Plus Project for Biomedical Science, Korea University College of Medicine, Seoul, Korea.

5. Department of Biomedical Sciences, Korea University College of Medicine, Seoul, Korea.

6. Department of Genetics, Yale University School of Medicine, New Haven, CT, US.

7. Department of Cancer Biology, Abrason Cancer Center, Perlman School of Medicine at the University of Pennsylvania, Philadelphia, PA, US.

8. Instituto de Fisiología, Biología Molecular y Neurociencias (IFIByNE), CONICET, Departamento de Fisiología y Biología Molecular y Celular. Facultad de Ciencias Exactas y Naturales, Universidad de Buenos Aires, Buenos Aires, Argentina

${ }^{*}$ Contributed Equally to this work.

Address Correspondence to:

Diego Y. Grinman, PhD

Section of Endocrinology and Metabolism

Yale School of Medicine

300 Cedar Street, TAC S120

Box 208020

New Haven, CT 06520-8020

diego.grinman@yale.edu 


\section{Abstract}

48 Background: Parathyroid hormone-related protein $(\mathrm{PTHrP})$ is required for embryonic

49 breast development and has important functions during lactation, when it is produced by

50 alveolar epithelial cells and secreted into the maternal circulation to mobilize skeletal

51 calcium used for milk production. PTHrP is also produced by breast cancers and GWAS

52 studies suggest that it influences breast cancer risk. However, the exact functions of

53 PTHrP in breast cancer biology remain unsettled.

54 Methods: We developed a tetracyline-regulated, MMTV (mouse mammary tumor

55 virus)-driven model of PTHrP overexpression in mammary epithelial cells (Tet-PTHrP

56 mice) and bred these mice with the MMTV-PyMT (polyoma middle tumor-antigen)

57 breast cancer model to analyze the impact of PTHrP overexpression on normal

58 mammary gland biology and in breast cancer progression.

59 Results: Overexpression of PTHrP in luminal epithelial cells caused alveolar

60 hyperplasia and secretory differentiation of the mammary epithelium with milk

61 production. This was accompanied by activation of Stat5 and increased expression of

62 E74-like factor-5 (Elf5). In MMTV-PyMT mice, overexpression of PTHrP (Tet-

63 PTHrP;PyMT mice) shortened tumor latency and accelerated tumor growth, ultimately

64 reducing overall survival. Tumors overproducing PTHrP also displayed increased

65 expression of nuclear pSTAT5 and Elf5, increased expression of markers of secretory

66 differentiation and milk constituents, and histologically resembled secretory carcinomas

67 of the breast. Overexpression of PTHrP within cells isolated from tumors, but not

68 PTHrP exogenously added to cell culture media, led to activation of STAT5 and milk 
69 protein gene expression. In addition, neither ablating the Type 1 PTH/PTHrP receptor

70 (PTH1R) in epithelial cells or treating Tet-PTHrP;PyMT mice with an anti-PTH1R

71 antibody prevented secretory differentiation or altered tumor latency. These data

72 suggest that PTHrP acts in a cell-autonomous, intracrine manner. Finally, expression of

73 PTHrP in human breast cancers is associated with expression of genes involved in milk

74 production and STAT5 signaling.

75 Conclusions: Our study suggests that PTHrP promotes pathways leading to secretory

76 differentiation and proliferation in both normal mammary epithelial cells and in breast

77 tumor cells.

79 Keywords

80 Lactation, Breast Cancer, Milk, Proliferation, Parathyroid hormone related protein,

81 PyMT, Secretory carcinoma of the breast, PTHLH

\section{Background}

Parathyroid hormone-related protein (PTHrP) was originally discovered as a

85 cause of elevated calcium levels in patients with cancer [1-3]. It is evolutionarily related

86 to parathyroid hormone (PTH) and the amino-terminal portions of both proteins are

87 highly homologous, allowing them to bind and activate the same Type $1 \mathrm{PTH} / \mathrm{PTHrP}$

88 receptor $(\mathrm{PTH} 1 \mathrm{R})[2,3]$. As a result, when $\mathrm{PTHrP}$ is secreted by tumors, it mimics $\mathrm{PTH}$, 
89 leading to excessive bone resorption and hypercalcemia. PTHrP also contributes to the

90 development and physiologic functions of a variety of tissues and it has been shown to

91 affect cell proliferation and cell death in a number of settings [2, 4-6]. While many of its

92 functions are mediated by the PTH1R, PTHrP can also remain within the cell to regulate

93 proliferation, differentiation and survival through an intracrine mode of action requiring

94 the translocation of PTHrP into the nucleus [3, 7-11]. Although nuclear translocation

95 appears to be important for PTHrP biology, details of this signaling pathway remain

96 obscure.

99 development in mice and humans [12-15]. PTHrP also has important functions during

101 secreted into both milk and the maternal circulation [16-18]. In the maternal circulation,

102 PTHrP acts on bone cells to mobilize calcium from the skeleton that is subsequently

103 used by the mammary gland for milk production. In addition, PTHrP in milk regulates

104 total body calcium accrual in suckling neonates, acting to coordinate maternal and

105 neonatal calcium economy [19].

PTHrP is also produced by breast cancers, contributing both to their growth and

107 to tumor-induced changes in systemic metabolism [6, 16, 20]. When produced by

108 breast cancer cells within the bone microenvironment, PTHrP contributes to osteolytic

109 bone destruction and the expansion of bone metastases [6, 21, 22]. In addition,

110 genome-wide association (GWAS) studies have implicated the PTHLH (PTHrP) gene as

111 a breast cancer susceptibility locus [16, 23-25], suggesting that it may contribute to 
112 early steps in transformation and/or cancer progression. However, the exact functions

113 of PTHrP in breast cancer biology remain unsettled. Different studies have reported

114 that its expression either correlates with increased or decreased metastases and

115 survival [11, 26-30]. Moreover, studies have variably reported that PTHrP either

116 stimulates or inhibits the proliferation, differentiation and survival of breast cancer cells

$117[5,6,11,22,31-34]$. These contradictory results concerning the role and prognostic

118 value of PTHrP expression in breast cancer underscore the need to better understand

119 how it modulates breast tumor growth and/or breast cancer susceptibility.

120 In order to examine the effects of PTHrP on mammary tumor development in

121 mice, we developed a tetracyline-regulated, MMTV-driven model of PTHrP

122 overexpression in mammary epithelial cells (MMTV-rtTA;tetO-PTHrP). We found that

123 overexpression of PTHrP in luminal epithelial cells caused alveolar hyperplasia and

124 secretory differentiation of the mammary epithelium enabling virgin mice to produce

125 milk. This phenotype was associated with activation of STAT5, and increased

126 expression of Elf5 (E74-like factor-5), both important regulators of alveolar secretory

127 differentiation [35-38]. Furthermore, overexpression of PTHrP in epithelial cells in

128 MMTV-PyMT mice dramatically promoted the formation of mammary tumors by

129 shortening tumor latency and accelerating tumor growth, ultimately reducing overall

130 survival. Interestingly, tumors overproducing PTHrP expressed markers of secretory

131 differentiation and expressed milk constituents. These data suggest that PTHrP

132 promotes pathways leading to secretory differentiation in both normal mammary

133 epithelial cells and in breast tumor cells. 


\section{Methods}

\section{Animals}

We used FVB female mice of various genotypes described below in all experiments. Male mice were not used because the focus of the study was on mammary gland development and breast cancer. All animal experiments were performed in accordance with institutional regulations after protocol review and approval by Yale University's Institutional Animal Care and Use Committee.

PTHrP;MMTV-PyMT; MMTV-Cre;PTH1R ${ }^{\text {loxllox }}$. We used a bi-transgenic, tetracycline-

147 the timing of PTHrP overexpression. MMTV-rtTA mice from the Chodosh laboratory

148 (University of Pennsylvania) [39] were bred to TetO-PTHrP responder mice generated

149 in by the Wysolmerski laboratory [40] to make the double transgenic MMTV-rtTA;TetO-

150 PTHrP (Tet-PTHrP) mice. MMTV-PyMT mice were purchased from Jackson

151 Laboratories on a FVB background and bred into our Tet-PTHrP mice to generate

152 MMTV-rtTA;TetO-PTHrP;MMTV-PyMT (Tet-PTHrP;PyMT) mice. MMTV-Cre (Jackson

153 Laboratories) and PTH1R ${ }^{\text {fl/fl }}$ mice (from Henry Kronenberg, Boston, MA) [41] were bred

154 into the MMTV-rtTA;TetO-PTHrP;MMTV-PyMT mice to generate MMTV-rtTA;TetO-

155 PTHrP;MMTV-PyMT;PTH1R ${ }^{\text {lox/lox }}$ (Tet-PTHrP;PyMT;PTH1RLox) and MMTV-rtTA;TetO- 
157 Doxycycline (Dox) (2mg/ml; Research Products International, Cat\# D43020) was

158 administered in $5 \%$ sucrose water and mice could drink ad libitum. Mice were followed

159 weekly for tumors. Once palpable, tumor size was measured weekly with calipers and

160 tumor volume calculated using the formula $0.5 \mathrm{x}$ length $\mathrm{x}$ width ${ }^{2}$. Mice were euthanized

161 when tumors reached approximately $1.5 \mathrm{~cm}$ in any dimension, or when they appeared

162 unhealthy during the course of the experiment, whichever was earlier.

\section{Biochemical measurements}

165 Assay Kit (DICA-500, BioAssay Systems) according to manufacturer's instructions.

166 Plasma PTHrP was measured using an immunoradiometric assay (DSL-8100; Beckman

167 Coulter) in which we substituted a rabbit anti-PTHrP (1-36) antibody generated in our 168 laboratory as capture antibody [42]. This assay has a sensitivity of $0.3 \mathrm{pM}$.

Whole-mount analysis

171 described [43]. Briefly, the no. 4 inguinal mammary glands were removed and mounted

172 on a microscope slide. The tissue was fixed in acid ethanol for $1 \mathrm{~h}$ at room temperature,

173 washed in $70 \%$ ethanol then distilled water and incubated in carmine aluminum stain

$174(0.2 \%$ carmine, $0.5 \%$ aluminum potassium sulfate) overnight at room temperature. After

175 staining, the mammary glands were dehydrated through graded ethanol and cleared in

176 acetone and then toluene before being mounted under glass coverslips using Permount

177 (Fisher Scientific, Cat\# SP15-100). 


\section{Histology and immunohistochemistry} (50mg/kg, Invitrogen). Whole mammary glands, tumors and lungs were removed,

181 weighed and fixed for 12 hours in $4 \%$ paraformaldehyde. After fixation in $4 \%$

182 paraformaldehyde, tissues were transferred to $70 \%$ ethanol, embedded in paraffin and

183 cut in $5 \mu \mathrm{m}$ thick sections. Pertinent slides were then either stained with hematoxylin 184 and eosin using standard conditions, used for immunohistochemistry, or processed for

185 measuring proliferation using anti-Bromodeoxyuridine-POD, Fab fragment Kit (Roche,

186 Cat\# 11585860001) or the Click-iT EdU Cell Proliferation Kit (Invitrogen Cat\# C10337).

187 Rates of proliferation were calculated by dividing the number of BrdU- or EdU-positive

188 nuclei by the total number of nuclei. Lungs were processed for histology and pulmonary

189 metastases quantified by examination of 10, H\&E-stained sections cut $105 \mu \mathrm{m}$ apart.

190 All immunohistochemistry included an IgG isotype control and the primary antibodies we

191 used were against phospho-Stat5 (Cell Signaling, Cat\# 9314), $\beta$-casein (Santa Cruz

192 Biotechnology, Cat\# sc-166530), Elf-5 (Santa Cruz Biotechnology, Cat\# sc-9645), NF1B

193 (Sigma, Cat\# HPA-0039556), Nkcc1 (gift from Dr. James Turner at National Institutes of

194 Health) and Npt2b (gift from Dr. Jürg Biber at University of Zurich). Staining was

195 detected using Vector Elite ABC kits (Vector Laboratories), Envision Plus (DAKO), or

196 M.O.M. Immunodetection Kit (Vector Laboratories, Cat) and we used 3,3'-

197 diaminobenzidine as a chromogen.

\section{RNA extraction and real-time RT-PCR}


Mammary glands and tumors were homogenized in $1 \mathrm{ml}$ TRIzol (Invitrogen, Cat\# 15596018) using an Ultraturrax T25 (Ika Labortechnik) on ice. Lysates were cleared at

$20113,000 \mathrm{~g}$ for $10 \mathrm{~min}$ at $4^{\circ} \mathrm{C}$. The RNA was isolated using PureLink RNA columns

202 (Invitrogen, Cat\# 12183025) according to the manufacturer's instructions. Total RNA

203 was quantified using a Nanodrop 1000 spectrophotometer (Thermo Fisher Scientific).

204 For all samples, the ratio of absorbance at $260 \mathrm{~nm}$ to absorbance at $280 \mathrm{~nm}$ was $>1.8$.

205 cDNA was synthesized using $1 \mu \mathrm{g}$ of total RNA with the High Capacity cDNA Reverse

206 Transcription Kit (Applied Biosystems, Cat\# 4368814) according to the manufacturer

207 instructions. Quantitative RT-PCR was performed using the Taqman Fast Universal

208 PCR Master Mix (Applied Biosystems, Cat\# 4352042) or Sybr Green PCR Master kit

209 (Applied Biosystems, Cat\# 4309155) and a StepOnePlus real-time PCR system

210 (Applied Biosystems). The following TaqMan primer sets were used: hPthlh

211 Hs00174969_m1, mPthlh Mm00436057, PTH1R Mm00441046, Wap

212 Mm00839913_m1, Lalba Mm00495258_m1, Csn1s1 Mm01160593_m1, Csn1s2a

213 Mm00839343_m1, Csn1s2b Mm00839674_m1, Csn2 Mm04207885_m1, Csn3

214 Mm02581554_m1, Elf5 Mm00468732_m1, Nfib Mm01257777_m1, Gata3

215 Mm01337570_m1, Hprt1 Mm03024075_m1, Actb (Cat\# 4352933E). The following

216 primer pairs for Sybr green were also used: Pymt fwd (5'-ctgctactgcacccagacaa-3') and

217 Pymt rev (5'-gcaggtaagaggcattctgc-3'), Actb fwd (5'-ccacacccgccaccagttc-3') and Actb

218 rev (5'-gacccattcccaccatcacacc-3'). Relative mRNA expression was determined using

219 the standard curve method with the StepOne software v2.3 (Applied Biosystems).

220 Tissue protein isolation and western blot 
222 were lysed in $1 \mathrm{ml}$ of RIPA lysis buffer $(10 \mathrm{mM}$ Tris $\cdot \mathrm{HCl} \mathrm{pH} \mathrm{8,140} \mathrm{mM} \mathrm{NaCl,} 1 \mathrm{mM}$

223 EDTA pH 8, 0.5mM EGTA pH 8, 1\% Triton X-100, 0.1\% deoxycholate, and $0.1 \%$ SDS)

224 supplemented with a cocktail of protease inhibitors (Thermo Scientific Cat\# 78429), 50

$225 \mathrm{mM} \mathrm{NaF}$, and $1 \mathrm{mM} \mathrm{Na} 3 \mathrm{VO} 4$ on ice. Samples were then homogenized using an

226 Ultraturrax T25 (Ika Labortechnik). Lysates were centrifugated at 13,000 g for $10 \mathrm{~min}$ at

$227 \quad 4^{\circ} \mathrm{C}$ and the supernatant was recovered. The samples were quantitated for total protein

228 using the Bradford protein assay (Bio-Rad Cat\# 5000001) following the manufacturer's

229 instructions. A $2 \mu \mathrm{g} / \mu \mathrm{l}$ protein solution containing sample buffer (Invitrogen Cat\#

230 NP0007) plus sample reducing agent (Invitrogen Cat\# NP0004) was prepared and 30ug

231 of total protein were loaded into precast, $4 \%$ to $12 \%$ Bis-Tris acrylamide gels (Thermo

232 Fisher Scientific, Cat\# NP0322) in MOPS buffer (Thermo Fisher Scientific, Cat\#

233 NP0001) and underwent electrophoresis, after which samples were transferred to

234 nitrocellulose membranes (Bio-Rad, Cat\# 1621112). Membranes were treated with

235 blocking buffer (LI-COR Biosciences, Cat\# 927-60001) for 1 hour at room temperature

236 and then incubated with the primary antibody overnight at $4^{\circ} \mathrm{C}$, followed by a dye

237 conjugated secondary antibody for 1 hour at room temperature. Membranes were

238 imaged and analyzed using the Odyssey IR imaging system (LI-COR Biosciences). The

239 primary antibodies used were: anti-PTHrP (Peprotech, Cat\# 500-P276), anti- $\beta$-casein

240 (Santa Cruz Cat\# 166530), anti-Elf5 (Santa Cruz Cat\# sc-9645), anti-NF1B (Sigma,

241 Cat\# HPA003956), anti-p(Tyr694)Stat5 (Cell Signaling, Cat\# \#9359), anti-Stat5 (Cell

242 Signaling, Cat\# \#94205), anti-Npt2b (gift from Dr. Jürg Biber at University of Zurich),

243 anti- $\beta$-Actin (Santa Cruz Cat\# sc-130656). The secondary antibodies used were anti- 
244 mouse (LI-COR, Cat\# 926-68022) and anti-Rabbit (LI-COR Biosciences, Cat\# 926-

245 32213)

\section{Tumor cell isolation and culture}

Tumor cells were isolated from transgenic mammary tumors as previously

248 described [42]. Briefly, dissected tumors were minced into fragments under sterile

249 conditions and subjected to enzymatic digestion with Collagenase-Type3 (Worthington,

250 Cat\#: LS004183) at 2mg/ml, Dispase (Gibco, Cat\#: 17105-041) at 2mg/ml, Gentamycin

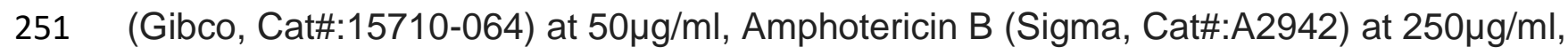

252 and 5\% FBS in DMEM/F12 media for 3 hours with intermittent shaking. Following

253 digestion, tumor organoids were pelleted, and then treated with $\mathrm{NH} 4 \mathrm{Cl}$ (Stem Cell

254 Technologies, Cat \# 07800) to lyse RBCs, following which, the pellet was washed three

255 times with PBS. Organoids were then passed through a $70 \mu \mathrm{m}$ cell strainer, counted

256 and used for transplantation experiments or cultured at a density of $3 \times 10^{6}$ cells $/ 55 \mathrm{~cm}^{2}$.

257 Proliferation of cultured cells was measured by assessing BrdU incorporation (Cell

258 proliferation ELISA Kit 11647229001 ; Roche $)$ after addition of Dox $(2 \mu \mathrm{g} / \mathrm{ml})$ or PTHrP

259 (Bachem, Cat\# 4017147.0500) to the culture media.

260 Tumor cell transplantation

500,000 freshly isolated, sterile tumor cells were suspended in $150 \mu$ of sterile

262 saline and were injected subcutaneously into the fat pad of 8 wild-type, adult FVB mice

263 via a small incision between the fourth nipple and the midline as previously described

264 [44]. Mice were treated with Dox 24 hours prior to the injection and were monitored for

265 tumor development. Mice were checked twice a week for tumors and tumor size was 
266 measured with calipers every other day. Tumor-bearing animals were euthanized

267 when the tumors reached approximately $1.5 \mathrm{~cm}$ in any dimension or when they

268 appeared unhealthy, whichever was earlier.

\section{Global gene expression profiling}

271 luminal epithelial cells of 4.5 week-old, MMTV-rtTA and Tet-PTHrP mice on Dox from

272 birth using antibodies against CD24 and CD49f cell surface markers as previously

273 described [45]. Similarly, total RNA was prepared from whole tumor lysates of MMTV-

274 PyMT and Tet-PTHrP;PyMT mice on Dox. The isolated RNA was purified using the

275 RNeasy cleanup kit (Qiagen). RNA was reverse-transcribed and hybridized to

276 Affymetrix Mouse Genome 4302.0 GeneChip by the Yale Center for Genomic Analysis.

277 Microarray data were analyzed with R version 4.1.2 and Bioconductor 3.14 [46]. Raw

278 data were MAS5 normalized and $\log _{2}$ transformed. 20,000 probes with the highest

279 statistical significance were selected as the first working matrix and then only genes

280 with fold change of $+/-2$ and $p<0.01$ were considered for further analyses. Differentially

281 expressed genes (DEGs) were analyzed using WikiPathways Pathway Analysis for

282 biological interpretation [47] and significant pathways were based on the Bonferroni

283 adjusted $p$ value ( $p a d j)<0.05$. Results of the functional analysis were combined and

284 integrated to the expression data with the GOplot package [48]. All statistical analyses

285 and data visualization plots were done with R/Bioconductor packages. GSEA analysis

286 was performed using previously generated set of 200 STAT5-dependent and

287 mammary tissue restricted genes [38]. Enrichment score curves and member ranks

288 were generated by the GSEA software package [49]. Volcano plots were constructed 
289 from the first selected 20,000 probes matrix with ggplot2 [50]. Heatmap was generated

290 with heatmap.2 package.

\section{Breast cancer single cell RNA seq data download and process}

294 and then analyzed using Seurat version 4.0 [51]. Seurat objects were created from 15

295 ER+, 6 HER2+ and 4 TNBC patient-derived datasets. Cells with $>60,000$ counts and

296 the number of unique genes detected in each cell were removed using $>200$ and $<$

2977,000 as criteria. This is a quality control step, as it is thought that cells with high

298 numbers of counts are more likely to be doublets while cells with low numbers of counts

299 are thought to be of poor data quality. Data normalization, variable feature detection,

300 feature scaling, and principal component analysis were performed in Seurat using

301 default parameters. Cell clusters were identified using the default Louvain clustering

302 algorithm implemented in Seurat. Default Seurat function settings were used except that

303 clustering resolutions were set to 0.5 and principal component dimensions 1:10 were

304 used for all dimension reduction and integration steps. Epithelial cells were identified

305 using canonical marker genes as described and normalized counts data were used in

306 all relevant downstream analysis [52]. Cells were divided into two groups depending on

307 their normalized counts of PTHLH expression level. PTHLH high groups expressed

308 PTHLH more than 0 and remaining cells were designated as the PTHLH low group.

309 Differential expression between PTHLH high and low groups was conducted using the

310 FindMarker function in Seurat package with MAST option. Pathway enrichment was

311 performed on ranked lists with fGSEA using HALLMARK gene set from MsigDB v7.4 
$312[49,53]$. After removing genes that are not expressed in any cell, protein coding genes

313 only were considered (refer to biomaRt package [54]).

314 Statistics

315 Results were expressed as means \pm SE of at least 3 independent experiments.

316 Statistical analyses were performed with Prism 9.0 (GraphPad Software) and consisted

317 of one-way ANOVA followed by Tukey's multiple comparisons test. Before statistical

318 analysis, Q-Q plot and Shapiro Wilks test were performed for normality.

319 Homoscedasticity was assessed with Levene's test. In figures, asterisks mean

320 significant differences between means.

322 Results

323 Overexpression of PTHrP in luminal epithelial cells causes alveolar hyperplasia

324 We created a tetracycline-regulated model of PTHrP overexpression using a well

325 described MMTV-rtTA mouse, that employs the mouse mammary tumor virus long

326 terminal repeat (MMTV) to drive expression of the reverse tetracycline transactivator

327 (rtTA) in mammary epithelial cells (MECs) [55]. When MMTV-rtTA mice were bred to a

328 mouse containing a tetracycline-responsive, human PTHrP transgene, (TetO-PTHrP

329 mice) [56], the resulting double-transgenic, MMTV-rtTA;TetO-PTHrP (Tet-PTHrP)

330 offspring demonstrated a significant induction of human PTHLH mRNA in mammary

331 glands upon treatment with Dox (Fig.1A). As expected, there was essentially no human 
332 PTHLH mRNA expressed in mammary glands from Tet-PTHrP mice in the absence of

333 Dox, nor was there induction of the endogenous mouse Pthlh gene in response to Dox.

In previous studies, overexpression of PTHrP in myoepithelial cells delayed

335 ductal elongation and this was also the case in Tet-PTHrP mice treated with Dox [56].

336 As shown in Fig.1B, at 5 weeks of age, the ducts in Tet-PTHrP virgin mice off Dox had

337 grown past the central lymph and displayed a dichotomous branching pattern typical of

338 the virgin mammary gland. By contrast, in Tet-PTHrP mice treated with Dox, the ducts

339 were foreshortened but hyperplastic in appearance. Ducts in MMTV-rtTA mice on Dox

340 were the same as those in Tet-PTHrP mice off Dox, demonstrating that the effects

341 observed were due to PTHrP and not to either Dox or rtTA. By 13 weeks of age, the

342 ducts in all genotypes had advanced to the borders of the fat pad but the glands of Dox-

343 treated Tet-PTHrP mice displayed obvious alveolar hyperplasia on whole mount,

344 reminiscent of normal glands in mid to late pregnancy. In fact, histologic examination of

345 mammary glands from the Dox-treated Tet-PTHrP mice demonstrated multiple clusters

346 of MECs forming alveolar structures (Fig. 1C). Since there was no apparent structural

347 or developmental difference between MMTV-rtTA mice on Dox and Tet-PTHrP mice off

348 Dox, nor leakiness of human PTHrP expression in the latter, subsequent experiments

349 used either of these genotypes interchangeably as controls.

350 Given the increased numbers of epithelial cells in the glands from Tet-PTHrP

351 mice treated with Dox, we assessed rates of epithelial cell proliferation by measuring

352 EdU incorporation. As shown in Fig 1D, there was a clear increase in EdU

353 incorporation in MECs in both ducts and terminal end buds (TEBs) in response to 
354 PTHrP overexpression. These data demonstrate that induction of PTHrP expression in

355 MECs leads to alveolar hyperplasia.

Overexpression of PTHrP Activates Secretory Differentiation of Mammary

357 Epithelial Cells. alveolar and ductal lumens with what appeared to be secretory material. In addition,

360 large lipid droplets were apparent in both the cells as well as the luminal space (Fig.

361 1C). These features suggested milk production, and milk-like fluid was evident upon

362 gross inspection of the intact mammary glands of Tet-PTHrP mice treated with Dox

363 (Additional File 1A).

In order to confirm that MECs underwent secretory differentiation in response to

365 PTHrP, we assayed differentiation markers typically expressed by MECs during

366 lactation $[35,57]$. As shown in Fig. 2A, Dox treatment induced the expression of $\beta$ -

367 casein and the sodium-phosphate transporter $2 \mathrm{~b}$ (NPT2b) as measured by

368 immunohistochemistry, while suppressing expression of the sodium-potassium-chloride

369 co-transporter (NKCC1) in MECs of virgin Tet-PTHrP mice. These changes were

370 identical to normal lactating controls but were absent in normal virgin controls and in

371 virgin Tet-PTHrP mice in the absence of Dox. We also assayed the expression of a

372 series of milk-protein genes by QPCR (Fig 2B). Overexpression of PTHrP caused the

373 induction of whey acidic protein (Wap), alpha lactalbumin (Lalba) and multiple casein

374 genes, none of which were expressed in the glands from virgin controls or in Tet-PTHrP

375 mice off Dox. As expected from the gene expression data and the immunostaining, 
376 PTHrP overexpression led to a significant increase in PTHrP protein levels as well as an

377 increase in $\beta$-casein and NPT2b protein expression in whole mammary gland lysates as

378 assessed by immunoblot (Fig 2C \& Additional File 1B).

Next, we examined whether alveolar hyperplasia and/or secretory differentiation in MECs required ongoing exposure to PTHrP. Female Tet-PTHrP mice were placed

381 on Dox at 8 weeks of age for 4 weeks and then were either euthanized immediately or

382 followed for an additional 6 weeks off Dox before being euthanized. Additional controls

383 included similar nulliparous, Tet-PTHrP mice treated with Dox for 10 continuous weeks

384 before euthanasia. As expected, PTHrP expression for 4 weeks or 10 weeks in adult

385 females triggered alveolar hyperplasia, activated the expression of $\beta$-casein and

386 NPT2b, and suppressed NKCC1 expression (Additional File 2). After the withdrawal of

387 Dox for 6 weeks, the alveolar hyperplasia had almost completely resolved histologically,

388 NPT2b staining was no longer observed and NKCC1 became evident. However, MECs

389 continued to express some $\beta$-casein, albeit principally within the lumen of the ducts and

390 at lower levels than in MECs from glands exposed to ongoing PTHrP overexpression.

391 These results suggest that alveolar hyperplasia and the mature secretory phenotype

392 requires ongoing exposure to $\mathrm{PTHrP}$ but that some changes in cell differentiation or cell

393 fate may persist after transient exposure to PTHrP.

394 Overexpression of PTHrP induces Changes in Gene Expression Similar to

395 Lactation 
398 pSTAT5, Elf 5 and Nuclear factor 1B (NF1B) [35, 38, 58, 59]. As seen in Fig. 2A,

399 immunohistochemistry demonstrated that Dox treatment of virgin Tet-PTHrP mice

400 induced the expression of PSTAT5 within MEC nuclei, mimicking the pattern typically

401 seen during lactation. There was also a clear increase in PSTAT5 in immunoblot

402 analyses of mammary glands taken from Tet-PTHrP mice on Dox, that was not present

403 in Tet-PTHrP mice off Dox (Fig. 2C and Additional File 1B). While nuclear staining for

404 ELF5 was evident in MECs from virgin controls and from Tet-PTHrP mice off Dox, the

405 staining intensity appeared increased in MECs from virgin Tet-PTHrP mice on Dox and

406 in lactating control mice (Fig. 2A). This impression was confirmed by an increase in Elf5

407 mRNA as assessed by QPCR (Fig 2B) as well as increased ELF5 protein levels as

408 measured by immunoblot (Fig 2C and Additional File 1B). Finally, expression of NF1B

409 as assessed by immunohistochemistry, QPCR and immunoblot was not clearly different

410 in lactating mammary glands or in mammary glands from Tet-PTHrP mice on Dox as

411 compared with glands from either control Tet-PTHrP mice off Dox or virgin mice.

412 Continued full expression of these transcription factors required the ongoing presence

413 of PTHrP, because withdrawal of PTHrP expression resulted in substantial reduction,

414 although not complete elimination of the immunostaining for pSTAT5 and ELF5. As

415 before, expression of NF1B was not affected by PTHrP expression (Supplemental Fig.

416 2).

We next performed an analysis of overall gene expression using oligonucleotide-

418 based microarrays. We compared mRNA expression patterns from luminal MECs

419 isolated from Tet-PTHrP mice on Dox to that of luminal MECs isolated from MMTV-rtTA

420 control mice on Dox. Using a log fold change (LFC) cutoff of 2 and an adjusted $p$ value 
421 of 0.01 , we found 1631 genes differentially expressed (597 increased and 1034

422 reduced) as a result of PTHrP expression (Fig. 3A). Pathway analysis demonstrated

423 that the differentially expressed transcripts comprised key pathways important for MEC

424 secretory differentiation, including PI3K/Akt signaling, fatty acid biosynthesis,

425 triglyceride biosynthesis and the mammary gland transition from pregnancy to lactation

426 (although this didn't quite reach statistical significance, padj=0.07), among others (Fig.

427 3B). A more detailed analysis of the genes involved in alveolar cell differentiation

428 revealed an increase in the levels of Elf5, Nf1b, Gata3, Sox9, Csn3, Tfap2c, PiK3r1,

429 Lalba, Cldn8 and Muc1 as well as a downregulation of Esr1, Pgr, Cav1, Cdo1 and

430 Ccnd2 transcripts, all changes consistent with the activation of a secretory program in

431 luminal cells similar to lactation [60-62] (Fig 3C). Taken together, these results

432 demonstrate that increased levels of PTHrP are sufficient to induce the expression of

433 lactation-associated transcription factors that subsequently cause secretory

434 differentiation and milk production in the absence of a prior pregnancy.

Overexpression of PTHrP accelerates tumor formation in MMTV-PyMT mice

We observed a cohort of 6 Tet-PTHrP mice on Dox for over a year (median 417

437 days) to determine whether the alveolar hyperplasia associated with PTHrP

438 overexpression would result in the formation of mammary tumors. Only 1 mouse

439 developed a tumor at 354 days, suggesting that PTHrP, itself, was not an efficient or

440 dominant oncoprotein. However, in order to determine whether PTHrP overexpression

441 might influence tumor formation caused by an established oncogene, we bred the

442 MMTV-PyMT transgene onto Tet-PTHrP mice to generate MMTV-rtTA;TetO-

443 PTHrP;MMTV-PyMT (Tet-PTHrP;PyMT) mice [63]. Continuous PTHrP overexpression 
444 from birth led to a dramatic acceleration of tumor formation (Fig. 4A). Microscopic

445 tumors developed in Tet-PTHrP;PyMT mice as early as 5-10 days of age (Additional

446 File $3 A$ ) and $100 \%$ of the mice had palpable masses in all mammary glands by just over

44720 days of age (median latency of 24 days) (Fig. 4A). In contrast, control Tet-

448 PTHrP;PyMT mice maintained off Dox developed tumors in only some glands between

$449 \quad 40-90$ days with a median latency of 71 days (Fig. 4A). PTHrP overexpression also

450 dramatically shortened survival (Fig. 4B). When treated with Dox, Tet-PTHrP;PyMT

451 mice became systemically ill, developed high circulating PTHrP and calcium levels (Fig.

$4524 \mathrm{C}$ ), and died before 40 days of age (median survival of 30 days). In contrast, control

453 Tet-PTHrP;PyMT mice off Dox appeared generally healthy, had normal PTHrP and

454 calcium levels, but were euthanized due to tumor size between 50 and 100 days of age

455 (median survival of 94 days). Importantly, overexpression of PTHrP did not increase

456 the expression of the MMTV-PyMT transgene in cells isolated from Tet-PTHrP;PyMT

457 tumors (Additional File 3B), demonstrating that acceleration of tumorigenesis was

458 caused by PTHrP and not by increased PyMT expression.

459 BrdU staining demonstrated that PTHrP increased cell proliferation in mammary

460 tumors from Tet-PTHrP;PyMT mice on Dox (Fig. 4D). Previous work has shown that

461 PTHrP can regulate G1-S cell-cycle progression in vascular smooth muscle and breast

462 cancer cells by modulating expression of the cell-cycle inhibitor, p27kip1 [42, 64, 65].

463 Therefore, we examined p27kip1 levels in tumors harvested from Tet-PTHrP;PyMT

464 mice on or off Dox and found that increasing PTHrP production decreased p27kip1

465 levels in mammary tumors (Fig. 4E). 
PTHrP overexpression leads to secretory differentiation of MMTV-PyMT tumor phenotype and prominent intracellular lipid droplets as well as secretory material in extracellular "lumens" between fronds of tumor cells (Fig 5A and Additional File 4A). In

471 addition, tumor dissection often revealed the presence of viscous white fluid resembling

472 milk (Additional File 4B). These changes were reminiscent of the secretory

473 differentiation seen in MECs of non-tumor bearing mice overexpressing PTHrP (Fig. 2).

474 Therefore, we performed immunohistochemistry to examine the same mammary

475 differentiation markers in tumor cells (Fig. 5A). Interestingly, tumors from control

476 MMTV-PyMT mice on Dox demonstrated low levels of immunostaining for $\beta$-casein,

477 NPT2b and pSTAT5, although expression of all three of these markers was significantly

478 upregulated in tumors from Tet-PTHrP;PyMT mice on Dox. In addition, NKCC1 expression was downregulated by PTHrP expression. Nuclear staining for ELF5 appeared more prominent in tumors overexpressing PTHrP but nuclear staining for

481 NF1B appeared unchanged. Western blot analyses from whole tumor lysates

482 demonstrated similar findings. Tumors from Tet-PTHrP;PyMT mice on Dox displayed

483 significantly higher levels of pSTAT5, $\beta$-casein and NPT2b than tumors from either

484 MMTV-PyMT mice on Dox or from Tet-PTHrP;PyMT mice off Dox (Fig. 5B). ELF5 and

485 NF1B levels in tumors taken from Tet-PTHrP;PyMT mice on Dox were not statistically

486 significantly different from controls. QPCR from whole tumors revealed a significant

487 elevation of Wap, Lalba and the different casein mRNA levels in response to PTHrP

488 overexpression. There was also a small increase in Elf5 gene expression but no 
489 change in Nf1b or Gata3 gene expression. Overall, these changes mirrored the

490 activation of secretory differentiation induced by PTHrP in normal MECs without the

491 PyMT oncogene.

Given the apparent increased level of differentiation of the cells, we also examined

493 whether tumors in Tet-PTHrP;PyMT mice on Dox continued to demonstrate malignant

494 behavior. First we examined lungs from these mice for metastases (Additional File 4C)

495 and found that 6 out of 10 Tet-PTHrP;PyMT mice treated with Dox developed lung

496 lesions. Among those, we counted an average of 6.17 lung metastasis per mice,

497 documenting that tumor cells retained the ability to disseminate and metastasize to

498 distant sites. We also transplanted isolated tumor cells from Tet-PTHrP;PyMT mice into

499 mammary fat pads of WT animals. In the presence of Dox, $75 \%$ of the 8 mice receiving

500 these cells developed tumors that secreted PTHrP into the circulation producing

501 significant hypercalcemia (Additional File 4D). These data demonstrate that PTHrP

502 overexpression did not extinguish the tumor-propagating potential of the cells.

503 Therefore, while PTHrP triggered a program of secretory differentiation in PyMT tumor

504 cells, it did so without reversing their transformed state.

Mammary tumors overexpressing PTHrP activate gene signatures that overlap

506 with STAT5 Signaling and Lactation

We reasoned that the development of secretory alveolar hyperplasia in the

508 mammary glands of the Tet-PTHrP mice and the formation of secretory

509 adenocarcinomas in Tet-PTHrP;PyMT mice are likely to be a consequence of the

510 activation of common STAT5-dependent pathways. To test this hypothesis, we 
511 performed a second microarray using RNA isolated from tumors of Tet-PTHrP;PyMT

512 mice on or off Dox. As before, we used a LFC cutoff of 2 and an adjusted p value of

5130.01 , and identified a total of 921 differentially expressed genes (686 reduced and 235

514 increased) in response to PTHrP overexpression (Additional File 5A). Pathway

515 analysis demonstrated that the differentially expressed transcripts could be grouped into

516 pathways involved in adipocyte differentiation, fatty acid metabolism and the mammary

517 gland transition from pregnancy to lactation, among others (Additional File 5B). We

518 then asked specifically whether mammary epithelial cell, STAT5-dependent genes were

519 activated in tumors overexpressing PTHrP by comparing the differentially expressed

520 genes from PTHrP-overexpressing tumors to a previously validated set of 200 STAT5-

521 dependent genes specific to mammary tissue [38]. Gene set enrichment analysis

522 demonstrated that overexpression of PTHrP led to a significant enrichment of Stat5-

523 dependent mRNAs in PyMT-derived tumors (Fig. 5D). To illustrate the induction of

524 STAT5-dependent genes, the accompanying heatmap shows relative changes in the

525 expression of 12 selected STAT5 target genes that are normally induced during

526 lactation and are also induced by PTHrP expression in tumors. The complete list of the

527 genes from the set and their relative change in expression in response to PTHrP

528 overexpression is shown in Additional File 5C.

529 Given the similarities in the secretory phenotypes induced by PTHrP in normal

530 MECs and in PyMT tumors, we directly compared differentially expressed genes

531 (DEGs) in PTHrP-overexpressing tumors from Tet-PTHrP;PyMT mice with DEGs in

532 PTHrP-overexpressing MECs from Tet-PTHrP mice (Fig. 6). There were 921 DEGs in

533 PTHrP-overexpressing tumors and 1,631 DEGs in PTHrP overexpressing luminal 
534 MECs. Comparing these sets of genes documented a substantial overlap with a shared

535 group of 652 genes (524 reduced and 128 increased) that were differentially expressed

536 in both settings. Analysis of the genes in the overlap showed expression of genes

537 involved in mammary gland development skewed toward lactation, as indicated by

538 upregulation of Elf5 and Ttc and downregulation of Cebp $\alpha$, Cav-1 and progesterone

539 receptor (Pgr) (Fig 6B). Stimulation of ELF5 and downregulation of Cav-1, PGR, and

540 changes in the PI3K/Akt pathway are all consistent with an increase in STAT5 signaling

$541[35,38,59-62,66,67]$. Overall, these results are consistent with the idea that PTHrP

542 overexpression leads to STAT5 activation and secretory differentiation in both normal

543 MECs as well as in PyMT-induced mammary tumors.

544 Activation of Stat5 in tumor cells by PTHrP is cell autonomous and independent

545 of PTH1R

546 PTHrP can signal through autocrine/paracrine mechanisms involving the activation

547 of its cell surface receptor (PTH1R) or, alternatively, through intracrine/nuclear

548 mechanisms $[4,5,7]$. Tran and colleagues had previously described correlations

549 between immunostaining for nuclear PTHrP and nuclear PSTAT5 expression in human

550 breast tumors [11]. Therefore, we hypothesized that PTHrP triggered secretory

551 differentiation in breast cancer cells through an intracrine pathway involving Stat5

552 activation. In order to test this idea, we treated cells derived from mammary tumors

553 from Tet-PTHrP;PyMT mice either with vehicle, Dox to induce endogenous PTHrP

554 expression or with exogenous PTHrP (100nM) added to the media. Treating the cells

555 with Dox caused increased pStat5 levels as assessed by Western analysis, whereas

556 adding PTHrP to the media of the cells did not (Fig. 7A). In both circumstances, cells 
557 were cultured in the absence of prolactin. Similarly, Dox treatment was associated with

558 an increase in the expression of various milk proteins by QPCR including Csn1s1,

559 Csn1s2a, Csn2 and Csn3, which, again, was not reproduced by treatment with

560 exogenous PTHrP (Fig. 7B). Finally, we examined cell proliferation as assessed by

561 BrdU incorporation. Induction of PTHrP with Dox treatment led to an increase in

562 proliferation of the cells while treatment with exogenous PTHrP did not (Fig. 7C).

563 These results suggest that the effects of PTHrP are cell autonomous, independent of

564 prolactin stimulation, and mediated by intracrine actions of PTHrP.

565

566

567

568

569

570

571

572

573

574 tetracycline-regulated PTHrP overexpression and MMTV-PyMT-mediated mammary

575 tumorigenesis. MMTV-rtTA;TetO-PTHrP; MMTV-PyMT; MMTV-Cre;PTH1R Rox/lox (Tet-

576 PTHrP;PyMT;Cre;PTH1RLox) mice on Dox were followed for the development of

577 mammary tumors and compared to Tet-PTHrP;PyMT;PTH1RLox mice that lacked the

578 Cre transgene. As shown in Fig. 8B, the incidence and latency of tumors as well as

579 survival in Tet-PTHrP;PyMT;Cre;PTH1RLox mice was no different than in Tet- 
580 PTHrP;PyMT;PTH1RLox mice. Tumor cells isolated from these mice demonstrated

581 successful reduction of Pth1r mRNA levels (Fig. 8C), but lack of PTH1R expression had

582 no effect on the expression of typical markers of lactation such as Wap, Lalba and

583 multiple casein genes in whole tumor lysates (Fig 8D). In addition, ablation of the

584 PTH1R had no effect on the expression of pSTAT5 in the nuclei of tumor cells (Fig. 8E).

585 We further confirmed that the effects of PTHrP were independent of the PTH1R by

586 treating Tet-PTHrP;PyMT mice with a blocking antibody against the PTH1R (anti-

587 PTH1R) or IgG control at the same time Dox was provided (Fig. 8F-I). As expected, Tet-

588 PTHrP;PyMT mice on Dox and treated with IgG developed hypercalcemia. However,

589 Tet-PTHrP;PyMT mice on Dox and treated with anti-PTH1R antibody had normal

590 calcium levels despite persistently elevated PTHrP levels, indicating that this treatment

591 is highly effective in blocking systemic PTH1R signaling (Fig. 8F\&G). In contrast,

592 treatment with anti-PTH1R antibody did not prevent the induction of milk protein gene

593 expression or STAT5 activation in tumor cells, demonstrating that the PTH1R is not

594 required for PTHrP to trigger secretory differentiation in tumors (Fig. 8H\&l). These

595 results are consistent with the experiments in vitro suggesting that PTHrP acts in an

596 intracrine manner.

597 PTHLH Gene Expression in Human Breast Cancer Cells Correlates with Increased

598 Expression of Genes Associated with Secretory Differentiation

In order to determine whether PTHrP production correlated with activation of

600 STAT5-dependent, secretory differentiation pathways in human breast cancer, we

601 examined recently published, single-cell sequencing data derived from 27 different

602 human breast tumors (8 TNBC, 6 HER2-pos, 13 ER-pos) [70]. We were able to define 
603 PTHLH-high and PTHLH-low subsets from the pooled sequencing data of 86,277

604 individual epithelial tumor cells (Fig. 9A). The PTHLH-high cells were a distinct minority

605 of the total cells and could be found at low levels in the three tumor sub-types.

606 However, TNBCs had significantly more PTHLH-high cells (8.92\%) than either HER2-

607 positive (1.55\%) or ER-positive (1.5\%) tumors (Fig. 9B). We then defined the DEGs in

608 PTHLH-high vs. PTHLH-low cells using pooled data from all tumor sub-types and

609 performed functional pathways analyses using GSEA. We found that the DEGs were

610 enriched in several pathways known to regulate aspects of lactation and milk production

611 including protein secretion, fatty acid metabolism, PI3K-AKT-MTOR signaling and

612 cholesterol homeostasis, as well as mitotic cell cycle and cell division processes (Fig.

613 9C). Importantly, GSEA confirmed that DEGs in PTHLH-high vs. PTHLH-low cells were

614 significantly enriched in the hallmark IL-2-STAT5 signaling pathway [71]. Overall, these

615 results suggest that high expression of PTHrP in human breast cancer cells is

616 associated with expression of genes involved in milk production and STAT5 signaling.

\section{Discussion}

The data presented in this study demonstrate that overexpression of PTHrP in

620 mammary epithelial cells activates a program of secretory differentiation. When treated

621 with Dox to induce human PTHrP (1-141) expression, the mammary glands of virgin,

622 Tet-PTHrP mice develop alveolar hyperplasia, express histological markers of secretory

623 differentiation, activate milk protein gene expression, and accumulate intracellular lipids.

624 These secretory changes are accompanied by the phosphorylation of STAT5 and an 
625 increase in the expression of ELF5, two pioneering transcription factors well described

626 to cooperate in driving gene expression necessary for milk production [35-38, 59].

627 Consistent with the activation of these transcription factors, we found that PTHrP

628 upregulates patterns of gene expression previously associated with lactation. Alveolar

629 hyperplasia and the expression of secretory differentiation markers are significantly

630 reversed in response to the withdrawal of Dox, suggesting that they depend on the

631 continuing presence of PTHrP. However, previous results from our lab demonstrated

632 that, although PTHrP expression is normally activated during lactation, mammary gland

633 specific ablation of PTHrP affects systemic calcium metabolism during lactation but

634 does not interfere with alveolar development or with overall milk secretion [17, 43].

635 Given the importance of lactation to mammalian reproduction, it is not surprising that the 636 pathways leading to secretory differentiation would be redundant. Nevertheless, these

637 new data clearly demonstrate that PTHrP is sufficient to induce secretory differentiation

638 in luminal epithelial cells in the absence of pregnancy.

640 MMTV-PyMT model of breast cancer. Tet-PTHrP;PyMT mice continuously exposed to

641 Dox develop tumors in all mammary glands by 3-4 weeks of age, a dramatic decrease

642 in tumor latency in comparison to Tet-PTHrP;PyMT mice not treated with Dox. While

643 PTHrP promoted premature growth of PyMT-associated mammary tumors,

644 overexpression of PTHrP alone did not efficiently induce tumors. Therefore, in this

645 setting, PTHrP appeared primarily to promote tumor growth rather than initiate

646 transformation. The decrease in tumor latency was accompanied by increased rates of

647 proliferation in the tumors. As noted previously in vascular smooth muscle cells and in 
648 human and murine breast tumor cells, increased proliferation was associated with

649 decreased expression of the cell cycle inhibitor, p27Kip1 [31, 72]. This acceleration of

650 tumor development is consistent with the reciprocal results of Li et al., who showed that

651 ablation of PTHrP expression in MMTV-PyMT tumors slowed tumor growth and was

652 associated with reduced proliferation and increased apoptosis [32]. They are also

653 consistent with prior results from our group demonstrating that ablation of the CaSR in

654 MMTV-PyMT tumors or in human BT474 and MDA.MB-231.1833 cells reduced PTHrP

655 expression, which was associated with a reduction in proliferation and increased

656 expression of p27kip1 [31]. Thus, although there have been variable reports on the

657 effects of PTHrP on human breast cancer cell lines, in mice, PTHrP clearly promotes

658 proliferation in mammary tumor cells expressing PyMT.

660 differentiation. This is associated with an increase in the expression of differentiation

661 markers, milk protein genes, Elf5, and pSTAT5. Despite an apparent shift to a more

662 differentiated state, tumors continued to metastasize, and cells derived from the tumors

663 overexpressing PTHrP were able to form new tumors when transplanted into non-

664 transgenic mice. The histological appearance of the tumors in Tet-PTHrP;PyMT mice,

665 their expression of pSTAT5 and the accumulation of milk-like secretions is reminiscent

666 of a rare type of human breast cancer known as "secretory carcinoma of the breast" [73-

667 77]. The majority of these tumors have been shown to contain $t(12 ; 15)(p 13 ; q 25)$

668 chromosomal translocations that results in a fusion oncogene (ETV6-NTRK3) consisting

669 of the oligomerization domain of ETV6 fused to the protein tyrosine kinase domain of

670 the neurotropin 3 receptor (NTRK3). Although most secretory carcinomas behave in an 
671 indolent manner, some patients developed metastatic lesions. When an ETV6-NTRK3

672 construct was knocked into mice, they developed mammary alveolar hyperplasia

673 followed by the development of multifocal tumors with short latency, again reminiscent

674 of the effects of overexpressing PTHrP on PyMT-mediated tumorigenesis [76].

675 Although there is no known link between PTHrP expression and the expression or

676 activity of NTRK3 or other neurotropin receptors, it has been suggested that the

677 transforming ability of the ETV6-NTRK3 fusion oncogene relies on activation of the AP1

678 transcription complex [76]. Given the similarities between PTHrP overexpression in

679 PyMT tumors and this model of secretory carcinomas, as well as the fact that PTHrP

680 has been shown to activate AP1 signaling by increasing c-fos and/or JunB expression in

681 several cell types, further study of potential interactions between PTHrP and AP1

682 signaling in breast cancer may be revealing [78, 79].

685 mediated by an intracrine pathway rather than through its cell surface receptor. First,

686 previous experiments overexpressing PTHrP in mammary gland myoepithelial cells did

687 not lead to alveolar hyperplasia and secretory differentiation although, similar to the

688 results reported here, it did inhibit ductal elongation during puberty $[56,68]$. These

689 differences are not compatible with a typical paracrine mode of action given that the 2

690 cell types overexpressing PTHrP in these different models are adjacent to each other.

691 Instead, the different phenotypes in these models suggest a cell-autonomous and cell-

692 restricted mechanism of action drives the secretory differentiation. Second, in cells

693 derived from Tet-PTHrP;PyMT mammary tumors, inducing PTHrP expression by 
694 treating them with Dox stimulates cell proliferation, activates STAT5 and increases milk

695 proteins gene expression, but treating the cells with exogenous PTHrP does not. Thus,

696 PTHrP is sufficient to induce secretory differentiation, but only if produced within the

697 tumor cells, suggesting a cell autonomous and intracrine mechanism. Third, reducing

698 PTH1R expression in tumor cells does not alter tumor growth or secretory differentiation

699 of the tumor cells, demonstrating that tumor expression of the PTH1R is not required for

700 the observed phenotype. Lastly, treating tumor-bearing Tet-PTHrP;PyMT mice with

701 anti-PTH1R antibodies corrects hypercalcemia but does not reverse STAT5 activation

702 or reduce the expression of secretory markers, demonstrating that secreted PTHrP

703 does not act systemically or on non-tumor cells in the microenvironment to induce

704 paracrine cascades supporting secretory differentiation. These results are consistent

705 with the observations of Tran et al., who previously reported that nuclear PTHrP staining

706 correlates with nuclear pSTAT5 staining in human breast cancers [11]. In addition,

707 Johnson et al. showed that PTHrP overexpression in MCF7 cells results in the

708 downregulation of several pro-dormancy genes and suggested that these actions may

709 occur through PTH1R-independent actions [69]. Finally, prior results from our

710 laboratory have demonstrated that intracrine/nuclear actions of PTHrP downstream of

711 the calcium-sensing receptor are important in modulating cell proliferation and survival

712 in human breast cancer cell lines and in PyMT-induced mouse mammary tumors [31].

$\mathrm{PTHrP}$ is widely recognized to be important for the progression of osteolytic bone

714 metastases from breast cancer [21, 80], although its role in the initiation, growth or

715 progression of primary breast tumors is less clear. The results we report here agree

716 with those of Li et al., demonstrating that PTHrP stimulates mammary tumor 
717 progression and results in shorter survival in MMTV-PyMT mice [32]. As compared to

718 studies in mice, PTHrP has been variably suggested to either promote or to inhibit

719 breast cancer cell proliferation, differentiation and death in human breast cancer cell

720 lines [5, 6, 11, 31, 34]. Likewise, studies examining PTHrP staining in human breast

721 cancers have reported differing correlations between PTHrP and tumor behavior. Some

722 studies have reported that PTHrP expression correlates with estrogen receptor and

723 progesterone receptor expression, a more differentiated histology, fewer metastases

724 and a better prognosis $[11,27]$. In contrast, other studies have suggested that

725 increased PTHrP expression predicts worse survival and increases brain or bone

726 metastases when measured in all breast tumors, in triple-negative breast cancers or in

727 circulating tumor cells [26, 29, 81, 82]. One possible explanation for these conflicting

728 results may be related to differing effects of PTHrP in luminal vs. triple negative sub-

729 types of breast cancer. Another may relate to our observation that PTHrP

730 overexpression results in the upregulation of STAT5 activation. STAT5 is critical to the

731 proliferation and secretory differentiation of normal breast epithelial cells during

732 pregnancy and lactation, but it seems to mirror PTHrP in having different effects on

733 tumor progression in mice and humans. Loss of STAT5 impedes the development of

734 tumors in T-antigen-dependent mouse models, while overexpression of wild-type or

735 constitutively active STAT5 accelerates tumor formation in these models [37, 83-85].

736 By contrast, the activation of STAT5 in human breast cancers has generally been

737 observed to be an indicator of more differentiated tumors and a better prognosis [11, 83,

738 86]. Our findings and those of Tran et al mirror the previous literature in that PTHrP

739 expression increases STAT5 and tumor progression in MMTV-PyMT mice, but PTHrP 
740 expression correlates with nuclear STAT5 expression and better outcome in human

741 breast cancer. This may not be the entire bottom line given the recent report from

742 Assaker and colleagues suggesting that tumor PTHrP expression at the time of

743 diagnosis correlated with subsequent brain metastases and poor survival in patients

744 with triple negative breast cancer (TNBC) [81]. Interestingly, we found the highest

745 numbers of cells with elevated PTHrP gene expression in TNBC's using single cell

746 sequencing data. Furthermore, genes potentially involved in Stat5 signaling were

747 enriched in TNBC cells expressing higher levels of PTHrP. Therefore, it is possible that

748 interactions between PTHrP and Stat5 may have different consequences depending on

749 the sub-type of breast cancer. Sorting out the details of when and how PTHrP affects

750 different breast cancers in different fashions will be critical to understanding the reported

751 association between the PTHLH gene and breast cancer in GWAS studies [23-25].

753 Conclusions

754 In summary, we report that PTHrP overexpression activates STAT5, increases

755 Elf5 expression, and leads to increased proliferation and secretory differentiation of both

756 normal luminal mammary epithelial and mammary tumor cells in mice. This is the result

757 of an intracrine pathway rather than a function of secreted PTHrP. We also find the

758 greatest proportion of individual human tumor cells with high PTHrP expression in triple

759 negative breast cancers, where higher PTHrP levels correlate with an enrichment of

760 STAT5-related gene expression. Further work to better understand how intracrine

761 PTHrP signaling interacts with STAT5 signaling may help to resolve conflicting 
762 published data regarding the overall effects of PTHrP on tumor behavior and patient

763 survival.

764

765 Declarations

766 Ethics approval and consent to participate

767 Not applicable

768 Consent for publication

769 Not applicable

770 Availability of data and materials

771 The dataset supporting the conclusions of this article is available in the ArrayExpress

772 database (http://www.ebi.ac.uk/arrayexpress) under accession number E-MTAB-11281.

773 Competing interests

774 The authors declare that they have no competing interests

775 Funding

776 This work was supported by NIH grants R01HD076248 and R01HD100468 to JJW. The

777 National Research Foundation of Korea (NRF) supported JC (No. NRF-

778 2019R1A4A1029000)

779 Author contributions 
780 DYG, KBG, FMT, LC, JJW conceived and designed research. DYG, KBG, FMT, PD,

$781 \mathrm{JRH}, \mathrm{CM}$ performed experiments. MGS, JL, JC curated and analyzed data. DYG, KBG,

782 FMT, LC, JJW interpreted results of experiments. DYG and JJW drafted manuscript. All

783 authors read and approved the final manuscript.

784 Acknowledgments

785 We are grateful to Dr. Henry Kronenberg for providing PTH1 $\mathrm{R}^{\mathrm{fl} / \mathrm{fl}}$ mice for our studies, to

786 Dr. James Turner for the anti-NKCC1 antibody and to Dr. Jürg Biber for the anti-NPT2b

787 antibody.

789 List of abbreviations

790 PTHrP: Parathyroid hormone-related protein

791 PTH: Parathyroid hormone

792 PTH1R: PTH/PTHrP receptor 1

793 MMTV: mouse mammary tumor virus long terminal repeat

794 ELF5: E74-like factor-5

795 TEB: Terminal end bud

796 MEC: Mammary epithelial cell

797 NKCC1: Sodium-potassium-chloride co-transporter 1

798 NPT2b: Sodium-phosphate transporter $2 b$

799 WAP: Whey acidic protein

800 LALBA: Alpha lactalbumin

801 DOX: Doxycycline 
802 NF1B: Nuclear factor 1B

803 GSEA: Gene set enrichment analysis

804 DEG: Differentially expressed gene

805 BrdU: Bromodeoxyuridine

806 EdU: 5-ethynyl-2'-deoxyuridine

807 TNBC: Triple negative breast cancer

808 ER: Estrogen receptor

809

810 Additional material

811 Additional File 1

812 .tiff

813 Overexpression of PTHrP causes milk production in mammary glands from virgin

814 mice. A) Picture of the number 4 inguinal mammary gland from virgin, 13-week-old Tet-

815 PTHrP mouse on dox showing milk accumulation. B) Densitometric quantification of the

816 western blots for the indicated milk proteins and secretory differentiation markers shown

817 in Figure 5. Bars represent mean \pm SEM, $n=3$ per group, ${ }^{* * *} p<0.0001^{* * *} p<0.001$

$818{ }^{* *} p<0.01{ }^{*} p<0.05$

819 Additional file 2.

820 .tiff

821 Alveolar hyperplasia and the mature secretory phenotype require ongoing

822 exposure to PTHrP. Immunohistochemical staining of mammary gland sections.

823 Representative images of an $n=3$ per group are shown. Scale bar $100 \mu m$. 


\section{Additional file 3.}

825 .tiff

827 early as 10 days of age. A) Whole-mount analysis of carmine-stained, inguinal

828 mammary glands from 10 day-old, Tet-PTHrP;PyMT mice on dox. Representative

829 images of two out of three mice. Scale bars $1 \mathrm{~mm}$ (left), 100 $\mu \mathrm{m}$ (right). B) QPCR

830 analysis of Pymt mRNA expression in RNA from isolated tumor cells. Actb was used as

831 a housekeeping gene. Bars represent mean \pm SEM, $n=6$, ns: not significant.

\section{$832 \quad$ Additional file 4.}

833 .tiff

\section{PTHrP induces secretory differentiation in PyMT tumor cells, without reversing}

835 their transformed state. A) H\&E staining of tumors from different mouse genotypes

836 and Dox treatments as detailed on the left. Representative images from 3 different

837 tumors and mice per group. Scale bar $100 \mu \mathrm{m} . \mathrm{B})$ Picture of the third and fourth

838 mammary gland containing tumors from Tet-PTHrP;PyMT mouse on Dox showing milk

839 accumulation. C) H\&E staining of lung sections from Tet-PTHrP;PyMT mice on Dox.

840 Black boxes highlight lung metastases. Representative images of metastasis from 3

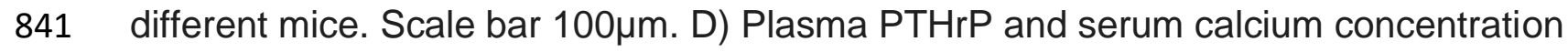

842 from WT mice on Dox transplanted with isolated Tet-PTHrP;PyMT tumor cells. Bars

843 represent mean \pm SEM, $n=6$.

\section{$844 \quad$ Additional file 5.}


846 Global mRNA profiling in tumors of Tet-PTHrP;PyMT and PyMT mice on Dox. A)

847 Volcano plot shows the $\log _{2}$ fold change and variance for all transcripts in PTHrP-

848 overexpressing tumors relative to controls. Lines illustrate 2 -fold changes and a padj of

849 0.01. Differentially expressed transcripts are highlighted in light blue and the number of

850 genes increased or decreased is indicated. B) Pathway analysis on differentially

851 expressed genes. Node size represents gene count; node color represents padj. C)

852 Heatmap of STAT5-dependent mammary gland genes comparing Tet-PTHrP;PyMT vs

853 PyMT mice on Dox using GSEA. N=3.

\section{References}

856 1. Stewart AF, Horst RL, Deftos LJ, Cadman EC, Lang R, Broadus AE: evidence for humoral and nonhumoral groups. New England Journal of Medicine 1980, 303:1377-1383.

2. Strewler GJ: The physiology of parathyroid hormone-related protein. $N$ Engl J Med 2000, 342(3):177-185.

3. Wysolmerski JJ: Parathyroid hormone-related protein: an update. J Clin Endocrinol Metab 2012, 97(9):2947-2956.

4. McCauley LK, Martin TJ: Twenty-five years of PTHrP progress: from cancer hormone to multifunctional cytokine. J Bone Miner Res 2012, 27(6):12311239.

5. Wysolmerski JJ: Parathyroid hormone-related protein: an update. J Clin Endocrinol Metab 2012, 97(9):2947-2956.

6. Zhang R, Li J, Assaker G, Camirand A, Sabri S, Karaplis AC, Kremer R: Parathyroid Hormone-Related Protein (PTHrP): An Emerging Target in Cancer Progression and Metastasis. Adv Exp Med Biol 2019, 1164:161-178.

7. Fiaschi-Taesch NM, Stewart AF: Minireview: parathyroid hormone-related protein as an intracrine factor--trafficking mechanisms and functional consequences. Endocrinology 2003, 144(2):407-411.

8. Jans DA, Thomas RJ, Gillespie MT: Parathyroid hormone-related protein (PTHrP): a nucleocytoplasmic shuttling protein with distinct paracrine and intracrine roles. Vitam Horm 2003, 66:345-384. 
878 9. Miao D, Su H, He B, Gao J, Xia Q, Zhu M, Gu Z, Goltzman D, Karaplis AC:

Severe growth retardation and early lethality in mice lacking the nuclear localization sequence and C-terminus of PTH-related protein. Proc Natl Acad Sci U S A 2008, 105(51):20309-20314.

10. Toribio RE, Brown HA, Novince CM, Marlow B, Hernon K, Lanigan LG, Hildreth BE, 3rd, Werbeck JL, Shu ST, Lorch G et al: The midregion, nuclear localization sequence, and $C$ terminus of PTHrP regulate skeletal development, hematopoiesis, and survival in mice. FASEB J 2010, 24(6):1947-1957.

11. Tran TH, Utama FE, Sato T, Peck AR, Langenheim JF, Udhane SS, Sun Y, Liu C, Girondo MA, Kovatich AJ et al: Loss of Nuclear Localized Parathyroid Hormone-Related Protein in Primary Breast Cancer Predicts Poor Clinical Outcome and Correlates with Suppressed Stat5 Signaling. Clin Cancer Res 2018, 24(24):6355-6366.

12. Cormier S, Delezoide AL, Silve C: Expression patterns of parathyroid hormone-related peptide (PTHrP) and parathyroid hormone receptor type 1 (PTHR1) during human development are suggestive of roles specific for each gene that are not mediated through the PTHrP/PTHR1 paracrine signaling pathway. Gene Expr Patterns 2003, 3(1):59-63.

13. Wysolmerski JJ, Cormier S, Philbrick WM, Dann P, Zhang JP, Roume J, Delezoide $A L$, Silve $C$ : Absence of functional type 1 parathyroid hormone (PTH)/PTH-related protein receptors in humans is associated with abnormal breast development and tooth impaction. J Clin Endocrinol Metab 2001, 86(4):1788-1794.

14. Wysolmerski JJ, Philbrick WM, Dunbar ME, Lanske B, Kronenberg H, Broadus $A E$ : Rescue of the parathyroid hormone-related protein knockout mouse demonstrates that parathyroid hormone-related protein is essential for mammary gland development. Development 1998, 125(7):1285-1294.

15. Hiremath M, Wysolmerski J: Parathyroid hormone-related protein specifies the mammary mesenchyme and regulates embryonic mammary development. Journal of mammary gland biology and neoplasia 2013, 18(2):171-177.

16. Grinman D, Athonvarungkul D, Wysolmerski J, Jeong J: Calcium Metabolism and Breast Cancer: Echoes of Lactation? Curr Opin Endocr Metab Res 2020, 15:63-70.

17. VanHouten JN, Dann P, Stewart AF, Watson CJ, Pollak M, Karaplis AC, Wysolmerski JJ: Mammary-specific deletion of parathyroid hormone-related protein preserves bone mass during lactation. J Clin Invest 2003, 112(9):1429-1436.

18. VanHouten JN, Wysolmerski JJ: Low estrogen and high parathyroid hormone-related peptide levels contribute to accelerated bone resorption and bone loss in lactating mice. Endocrinology 2003, 144(12):5521-5529.

19. Mamillapalli R, VanHouten J, Dann P, Bikle D, Chang W, Brown E, Wysolmerski $\mathrm{J}$ : Mammary-specific ablation of the calcium-sensing receptor during lactation alters maternal calcium metabolism, milk calcium transport, and neonatal calcium accrual. Endocrinology 2013, 154(9):3031-3042. 
924 20. Kim W, Wysolmerski JJ: Calcium-Sensing Receptor in Breast Physiology and Cancer. Front Physiol 2016, 7:440.

21. Akhtari M, Mansuri J, Newman KA, Guise TM, Seth P: Biology of breast cancer bone metastasis. Cancer Biol Ther 2008, 7(1):3-9.

22. Martin TJ, Johnson RW: Multiple actions of parathyroid hormone-related protein in breast cancer bone metastasis. Br J Pharmacol 2021, 178(9):19231935.

23. Purrington KS, Slager S, Eccles D, Yannoukakos D, Fasching PA, Miron P, Carpenter J, Chang-Claude J, Martin NG, Montgomery GW et al: Genome-wide association study identifies $\mathbf{2 5}$ known breast cancer susceptibility loci as risk factors for triple-negative breast cancer. Carcinogenesis 2014, 35(5):1012-1019.

24. Teraoka SN, Bernstein JL, Reiner AS, Haile RW, Bernstein L, Lynch CF, Malone KE, Stovall M, Capanu M, Liang X et al: Single nucleotide polymorphisms associated with risk for contralateral breast cancer in the Women's Environment, Cancer, and Radiation Epidemiology (WECARE) Study. Breast Cancer Res 2011, 13(6):R114.

25. Zeng C, Guo X, Long J, Kuchenbaecker KB, Droit A, Michailidou K, Ghoussaini M, Kar S, Freeman A, Hopper JL et al: Identification of independent association signals and putative functional variants for breast cancer risk through fine-scale mapping of the 12p11 locus. Breast Cancer Res 2016, 18(1):64.

26. Bundred NJ, Walls J, Ratcliffe WA: Parathyroid hormone-related protein, bone metastases and hypercalcaemia of malignancy. Ann R Coll Surg Engl 1996, 78(4):354-358.

27. Henderson MA, Danks JA, Slavin JL, Byrnes GB, Choong PF, Spillane JB, Hopper JL, Martin TJ: Parathyroid hormone-related protein localization in breast cancers predict improved prognosis. Cancer Res 2006, 66(4):22502256.

28. Hoey RP, Sanderson C, Iddon J, Brady G, Bundred NJ, Anderson NG: The parathyroid hormone-related protein receptor is expressed in breast cancer bone metastases and promotes autocrine proliferation in breast carcinoma cells. Br J Cancer 2003, 88(4):567-573.

29. Linforth R, Anderson N, Hoey R, Nolan T, Downey S, Brady G, Ashcroft L, Bundred $\mathrm{N}$ : Coexpression of parathyroid hormone related protein and its receptor in early breast cancer predicts poor patient survival. Clin Cancer Res 2002, 8(10):3172-3177.

30. Takagaki K, Takashima T, Onoda N, Tezuka K, Noda E, Kawajiri H, Ishikawa T, Hirakawa K: Parathyroid hormone-related protein expression, in combination with nodal status, predicts bone metastasis and prognosis of breast cancer patients. Exp Ther Med 2012, 3(6):963-968.

31. Kim W, Takyar FM, Swan K, Jeong J, VanHouten J, Sullivan C, Dann P, Yu H, Fiaschi-Taesch N, Chang W et al: Calcium-Sensing Receptor Promotes Breast Cancer by Stimulating Intracrine Actions of Parathyroid HormoneRelated Protein. Cancer Res 2016, 76(18):5348-5360. 
32. Li J, Karaplis AC, Huang DC, Siegel PM, Camirand A, Yang XF, Muller WJ, Kremer R: PTHrP drives breast tumor initiation, progression, and metastasis in mice and is a potential therapy target. J Clin Invest 2011, 121(12):4655-4669.

33. Luparello C: Parathyroid Hormone-Related Protein (PTHrP): A Key Regulator of Life/Death Decisions by Tumor Cells with Potential Clinical Applications. Cancers (Basel) 2011, 3(1):396-407.

34. Luparello $C$, Sirchia R, Lo Sasso B: Midregion PTHrP regulates Rip1 and caspase expression in MDA-MB231 breast cancer cells. Breast Cancer Res Treat 2008, 111(3):461-474.

35. Choi YS, Chakrabarti R, Escamilla-Hernandez R, Sinha S: Elf5 conditional knockout mice reveal its role as a master regulator in mammary alveolar development: failure of Stat5 activation and functional differentiation in the absence of Elf5. Dev Biol 2009, 329(2):227-241.

36. Frend HT, Watson CJ: Elf5 - breast cancer's little helper. Breast Cancer Res 2013, 15(2):307.

37. Furth PA, Nakles RE, Millman S, Diaz-Cruz ES, Cabrera MC: Signal transducer and activator of transcription 5 as a key signaling pathway in normal mammary gland developmental biology and breast cancer. Breast Cancer Res 2011, 13(5):220.

38. Metser G, Shin HY, Wang C, Yoo KH, Oh S, Villarino AV, O'Shea JJ, Kang K, Hennighausen $L$ : An autoregulatory enhancer controls mammary-specific STAT5 functions. Nucleic Acids Res 2016, 44(3):1052-1063.

39. Gunther EJ, Belka GK, Wertheim GBW, Wang J, Hartman JL, Boxer RB, Chodosh LA: A novel doxycycline-inducible system for the transgenic analysis of mammary gland biology. The FASEB Journal 2002, 16(3):283-292.

40. Dunbar M, Dann P, Brown C, Van Houton J, Dreyer B, Philbrick W, Wysolmerski $\mathrm{J}$ : Temporally regulated overexpression of parathyroid hormone-related protein in the mammary gland reveals distinct fetal and pubertal phenotypes. Journal of Endocrinology 2001, 171(3):403-416.

41. Kobayashi T, Chung U-I, Schipani E, Starbuck M, Karsenty G, Katagiri T, Goad DL, Lanske B, Kronenberg HM: PTHrP and Indian hedgehog control differentiation of growth plate chondrocytes at multiple steps. Development 2002, 129(12):2977-2986.

42. Kim W, Takyar FM, Swan K, Jeong J, Vanhouten J, Sullivan C, Dann P, Yu H, Fiaschi-Taesch N, Chang W et al: Calcium-Sensing Receptor Promotes Breast Cancer by Stimulating Intracrine Actions of Parathyroid HormoneRelated Protein. Cancer Research 2016, 76(18):5348-5360.

43. Boras-Granic K, VanHouten J, Hiremath M, Wysolmerski J: Parathyroid hormone-related protein is not required for normal ductal or alveolar development in the post-natal mammary gland. PLOS One 2011, 6(11):e27278.

44. Kocatürk B, Versteeg HH: Orthotopic Injection of Breast Cancer Cells into the Mammary Fat Pad of Mice to Study Tumor Growth. Journal of Visualized Experiments 2015(96). 
1014

1015

1016

1017

1018

1019

1020

1021

1022

1023

1024

1025

1026

1027

1028

1029

1030

1031

1032

1033

1034

1035

1036

1037

1038

1039

1040

1041

1042

1043

1044

1045

1046

1047

1048

1049

1050

1051

1052

1053

1054

1055

1056

1057

1058

45. Yamaji D, Na R, Feuermann Y, Pechhold S, Chen W, Robinson GW, Hennighausen L: Development of mammary luminal progenitor cells is controlled by the transcription factor STAT5A. Genes \& Development 2009, 23(20):2382-2387.

46. Huber W, Carey VJ, Gentleman R, Anders S, Carlson M, Carvalho BS, Bravo HC, Davis S, Gatto L, Girke T et al: Orchestrating high-throughput genomic analysis with Bioconductor. Nature Methods 2015, 12(2):115-121.

47. Martens M, Ammar A, Riutta A, Waagmeester A, Denise, Hanspers K, Ryan, Digles D, Elisson, Ehrhart $\mathrm{F}$ et al: WikiPathways: connecting communities. Nucleic Acids Research 2021, 49(D1):D613-D621.

48. Walter W, Sánchez-Cabo F, Ricote M: GOplot: an R package for visually combining expression data with functional analysis: Fig. 1. Bioinformatics 2015, 31(17):2912-2914.

49. Subramanian A, Tamayo P, Mootha VK, Mukherjee S, Ebert BL, Gillette MA, Paulovich A, Pomeroy SL, Golub TR, Lander ES et al: Gene set enrichment analysis: A knowledge-based approach for interpreting genome-wide expression profiles. Proceedings of the National Academy of Sciences 2005, 102(43):15545-15550.

50. H W: ggplot2: Elegant Graphics for Data Analysis: Springer-Verlag; 2016.

51. Hao Y, Hao S, Andersen-Nissen E, Mauck WM, Zheng S, Butler A, Lee MJ, Wilk AJ, Darby C, Zager $M$ et al: Integrated analysis of multimodal single-cell data. Cell 2021, 184(13):3573-3587.e3529.

52. Pal B, Chen Y, Vaillant F, Capaldo BD, Joyce R, Song X, Bryant VL, Penington JS, Di Stefano L, Tubau Ribera $\mathrm{N}$ et al: A single-cell RNA expression atlas of normal, preneoplastic and tumorigenic states in the human breast. The EMBO Journal 2021, 40(11).

53. Korotkevich G, Sukhov V, Budin N, Shpak B, Artyomov MN, Sergushichev A: Fast gene set enrichment analysis. In.: Cold Spring Harbor Laboratory; 2016.

54. Durinck S, Spellman PT, Birney E, Huber W: Mapping identifiers for the integration of genomic datasets with the R/Bioconductor package biomaRt. Nature Protocols 2009, 4(8):1184-1191.

55. Ecker BL, Lee JY, Sterner CJ, Solomon AC, Pant DK, Shen F, Peraza J, Vaught L, Mahendra S, Belka GK et al: Impact of obesity on breast cancer recurrence and minimal residual disease. Breast Cancer Res 2019, 21(1):41.

56. Dunbar ME, Dann P, Brown CW, Van Houton J, Dreyer B, Philbrick WP, Wysolmerski JJ: Temporally regulated overexpression of parathyroid hormone-related protein in the mammary gland reveals distinct fetal and pubertal phenotypes. $J$ Endocrinol 2001, 171(3):403-416.

57. Anderson SM, Rudolph MC, McManaman JL, Neville MC: Key stages in mammary gland development. Secretory activation in the mammary gland: it's not just about milk protein synthesis! Breast Cancer Res 2007, 9(1):204.

58. Mukhopadhyay SS, Wyszomierski SL, Gronostajski RM, Rosen JM: Differential interactions of specific nuclear factor I isoforms with the glucocorticoid receptor and STAT5 in the cooperative regulation of WAP gene transcription. Mol Cell Biol 2001, 21(20):6859-6869. 
59. Shin HY, Willi M, HyunYoo K, Zeng X, Wang C, Metser G, Hennighausen L: Hierarchy within the mammary STAT5-driven Wap super-enhancer. Nat Genet 2016, 48(8):904-911.

60. Andrechek ER, Mori S, Rempel RE, Chang JT, Nevins JR: Patterns of cell signaling pathway activation that characterize mammary development. Development 2008, 135(14):2403-2413.

61. Clarkson RW, Wayland MT, Lee J, Freeman T, Watson CJ: Gene expression profiling of mammary gland development reveals putative roles for death receptors and immune mediators in post-lactational regression. Breast Cancer Res 2004, 6(2):R92-109.

62. Rudolph MC, McManaman JL, Hunter L, Phang T, Neville MC: Functional development of the mammary gland: use of expression profiling and trajectory clustering to reveal changes in gene expression during pregnancy, lactation, and involution. J Mammary Gland Biol Neoplasia 2003, 8(3):287-307.

63. Attalla S, Taifour T, Bui T, Muller W: Insights from transgenic mouse models of PyMT-induced breast cancer: recapitulating human breast cancer progression in vivo. Oncogene 2021, 40(3):475-491.

64. Fiaschi-Taesch N, Sicari B, Ubriani K, Cozar-Castellano I, Takane KK, Stewart AF: Mutant parathyroid hormone-related protein, devoid of the nuclear localization signal, markedly inhibits arterial smooth muscle cell cycle and neointima formation by coordinate up-regulation of p15Ink4b and p27kip1. Endocrinology 2009, 150(3):1429-1439.

65. Fiaschi-Taesch N, Takane KK, Masters S, Lopez-Talavera JC, Stewart AF: Parathyroid-hormone-related protein as a regulator of $\mathrm{pRb}$ and the cell cycle in arterial smooth muscle. Circulation 2004, 110(2):177-185.

66. Radler PD, Wehde BL, Wagner KU: Crosstalk between STAT5 activation and $\mathrm{PI} 3 \mathrm{~K} / \mathrm{AKT}$ functions in normal and transformed mammary epithelial cells. Mol Cell Endocrinol 2017, 451:31-39.

67. Sotgia F, Schubert W, Pestell RG, Lisanti MP: Genetic ablation of caveolin-1 in mammary epithelial cells increases milk production and hyper-activates STAT5a signaling. Cancer Biol Ther 2006, 5(3):292-297.

68. Dunbar ME, Young P, Zhang JP, McCaughern-Carucci J, Lanske B, Orloff JJ, Karaplis A, Cunha G, Wysolmerski JJ: Stromal cells are critical targets in the regulation of mammary ductal morphogenesis by parathyroid hormonerelated protein. Dev Biol 1998, 203(1):75-89.

69. Johnson RW, Sun Y, Ho PWM, Chan ASM, Johnson JA, Pavlos NJ, Sims NA, Martin TJ: Parathyroid Hormone-Related Protein Negatively Regulates Tumor Cell Dormancy Genes in a PTHR1/Cyclic AMP-Independent Manner. Front Endocrinol (Lausanne) 2018, 9:241.

70. Pal B, Chen Y, Vaillant F, Capaldo BD, Joyce R, Song X, Bryant VL, Penington JS, Di Stefano L, Tubau Ribera $\mathrm{N}$ et al: A single-cell RNA expression atlas of normal, preneoplastic and tumorigenic states in the human breast. $E M B O \mathrm{~J}$ 2021, 40(11):e107333. 
1103 71. Liberzon A, Birger C, Thorvaldsdottir H, Ghandi M, Mesirov JP, Tamayo P: The

Molecular Signatures Database (MSigDB) hallmark gene set collection. Cell Syst 2015, 1(6):417-425.

72. Fiaschi-Taesch N, Sicari BM, Ubriani K, Bigatel T, Takane KK, Cozar-Castellano I, Bisello A, Law B, Stewart AF: Cellular mechanism through which parathyroid hormone-related protein induces proliferation in arterial smooth muscle cells: definition of an arterial smooth muscle PTHrP/p27kip1 pathway. Circ Res 2006, 99(9):933-942.

73. Gong P, Xia C, Yang Y, Lei W, Yang W, Yu J, Ji Y, Ren L, Ye F: Clinicopathologic profiling and oncologic outcomes of secretory carcinoma of the breast. Sci Rep 2021, 11(1):14738.

74. Hoda RS, Brogi E, Pareja F, Nanjangud G, Murray MP, Weigelt B, Reis-Filho JS, Wen HY: Secretory carcinoma of the breast: clinicopathologic profile of 14 cases emphasising distant metastatic potential. Histopathology 2019, 75(2):213-224.

75. Krings G, Joseph NM, Bean GR, Solomon D, Onodera C, Talevich E, Yeh I, Grenert JP, Hosfield E, Crawford ED et al: Genomic profiling of breast secretory carcinomas reveals distinct genetics from other breast cancers and similarity to mammary analog secretory carcinomas. Mod Pathol 2017, 30(8):1086-1099.

76. Li Z, Tognon CE, Godinho FJ, Yasaitis L, Hock H, Herschkowitz JI, Lannon CL, Cho E, Kim SJ, Bronson RT et al: ETV6-NTRK3 fusion oncogene initiates breast cancer from committed mammary progenitors via activation of AP1 complex. Cancer Cell 2007, 12(6):542-558.

77. Strauss BL, Bratthauer GL, Tavassoli FA: STAT 5a expression in the breast is maintained in secretory carcinoma, in contrast to other histologic types. Hum Pathol 2006, 37(5):586-592.

78. Berry JE, Ealba EL, Pettway GJ, Datta NS, Swanson EC, Somerman MJ, McCauley LK: JunB as a downstream mediator of PTHrP actions in cementoblasts. J Bone Miner Res 2006, 21(2):246-257.

79. Ionescu AM, Schwarz EM, Vinson C, Puzas JE, Rosier R, Reynolds PR, O'Keefe RJ: PTHrP modulates chondrocyte differentiation through AP-1 and CREB signaling. J Biol Chem 2001, 276(15):11639-11647.

80. Casimiro S, Guise TA, Chirgwin J: The critical role of the bone microenvironment in cancer metastases. Mol Cell Endocrinol 2009, 310(12):71-81.

81. Assaker G, Camirand A, Abdulkarim B, Omeroglu A, Deschenes J, Joseph K, Noman ASM, Ramana Kumar AV, Kremer R, Sabri S: PTHrP, A Biomarker for CNS Metastasis in Triple-Negative Breast Cancer and Selection for Adjuvant Chemotherapy in Node-Negative Disease. JNCl Cancer Spectr 2020, 4(1):pkz063.

82. Skondra M, Gkioka E, Kostakis ID, Pissimissis N, Lembessis P, Pectasides D, Koutsilieris M: Detection of circulating tumor cells in breast cancer patients using multiplex reverse transcription-polymerase chain reaction and specific primers for MGB, PTHRP and KRT19 correlation with clinicopathological features. Anticancer Res 2014, 34(11):6691-6699. 
83. Barash I: Stat5 in the mammary gland: controlling normal development and cancer. J Cell Physiol 2006, 209(2):305-313.

84. Ren S, Cai HR, Li M, Furth PA: Loss of Stat5a delays mammary cancer progression in a mouse model. Oncogene 2002, 21(27):4335-4339.

85. Schmidt JW, Wehde BL, Sakamoto K, Triplett AA, Anderson SM, Tsichlis PN, Leone G, Wagner KU: Stat5 regulates the phosphatidylinositol 3-kinase/Akt1 pathway during mammary gland development and tumorigenesis. Mol Cell Biol 2014, 34(7):1363-1377.

86. Nevalainen MT, Xie J, Torhorst J, Bubendorf L, Haas P, Kononen J, Sauter G, Rui $\mathrm{H}$ : Signal transducer and activator of transcription- 5 activation and breast cancer prognosis. J Clin Oncol 2004, 22(11):2053-2060.

Figure legends

Figure 1. PTHrP overexpression causes alveolar hyperplasia. A) Relative expression of mouse and human PTHLH mRNA in mammary gland lysates. Hprt1 was used as housekeeping gene. Bars represent mean \pm SEM of fold change versus TetPTHrP off dox, $n=5$ mice per group. B) Whole-mount analysis of carmine-stained number 4 inguinal mammary glands from mice at 5 and 13 weeks. Scale bar $5 \mathrm{~mm}$. C) H\&E stained cross-sections from 13-week-old mice. Scale bar 100 $\mu$ m. D) Representative images and quantification of EdU incorporation in sections of mammary glands from mice at 5 weeks of age. Bar graphs represent the percentage of Edupositive cells over a minimum of 1000 total nuclei (DAPI). N=3 mice per group, ${ }^{* * * *} p<0.0001{ }^{* *} p<0.01$.

\section{Figure 2. PTHrP overexpression induces the expression of milk proteins and} markers of secretory differentiation. A) Immunohistochemical staining of mammary gland sections of 8-12-week-old mice. Representative images from each group are shown. $\mathrm{N}=3$, Scale bar $100 \mu \mathrm{m}$. B) QPCR analysis for the expression of milk protein and transcription factor genes from whole mammary glands of 8-12-week-old mice. 
1177 Hprt1 was used as housekeeping gene. C) Western blot analysis of protein lysates from

1178 mammary glands of 8-12-week-old mice. Samples from three different mice per group

1179 were run with $\beta$-Actin as the loading control. Bars represent mean $\pm \mathrm{SEM}, \mathrm{n}=3$ per

1180 group, ${ }^{* * *} \mathrm{p}<0.0001^{* * *} \mathrm{p}<0.001^{* *} \mathrm{p}<0.01^{*} \mathrm{p}<0.05$

1181 Figure 3. PTHrP induces changes in genes involved in secretory differentiation in

1182 luminal cells. Global mRNA profiling was performed in FACS sorted luminal mammary

1183 epithelial cells isolated from 4.5-week-old MMTV-rtTA and Tet-PTHrP mice on Dox from

1184 birth. A) Volcano plot shows the log2 fold change and variance for all transcripts in Tet-

1185 PTHrP cells relative to controls. Lines illustrate 2-fold changes and a padj of 0.01.

1186 Differentially expressed transcripts are highlighted in light blue and the number of genes

1187 increased or decreased is indicated. B) Heatmap showing relative expression change of

1188 representative genes involved in mammary gland secretory differentiation. C) Pathway

1189 analysis on differentially expressed genes. Node size represents gene count; node color

1190 represents padj.

1191 Figure 4. Overexpression of PTHrP accelerates tumor formation in MMTV-PyMT

1192 mice. Kaplan-Meier analysis of $(\mathrm{A})$ tumor onset and (B) survival in Tet-PTHrP;PyMT

1193 mice on Dox (red) vs Tet-PTHrP;PyMT mice off Dox (blue) . (C) Circulating levels of

1194 plasma PTHrP and serum calcium concentration. (D) Quantitation of BrdU incorporation

1195 in tumor sections. Results are expressed as the percentage of BrdU-positive cells over

1196 a minimum of 1000 total cells. (E) Expression levels of $p 27 k i p 1$ mRNA relative to $\beta$-actin

1197 mRNA in tumors. Bars represent mean \pm SEM, a minimum of $n=3$ per group,

$1198{ }^{* * *} p<0.0001^{* *} p<0.01{ }^{*} p<0.05$ 
Figure 5. PTHrP overexpression causes secretory differentiation and Stat5

1200 activation in PyMT tumors. (A) H\&E and immunohistochemical analysis of tumors

1201 from Tet-PTHrP;PyMT mice on Dox and controls. Representative images from each

1202 group are shown. N=3. (B) Western Blots on protein lysates from whole tumors. Left

1203 shows Samples from three different mice per group were run with $\beta$-Actin as the loading

1204 control. Right shows the densitometric quantification of western blots. (C) QPCR

1205 analysis for the indicated genes of RNA isolated from whole tumors. Hprt1 was used as

1206 housekeeping gene. N=3. D) Left shows the custom GSEA for STAT5-dependent

1207 mammary gland genes comparing Tet-PTHrP;PyMT vs PyMT mice on dox. Nom $p$ -

1208 value, normalized $p$-value; FDR, false discovery rate; NES, normalized enrichment

1209 score. Right, heatmap depicting relative expression change of representative STAT5-

1210 dependent genes. Bars represent mean \pm SEM, ${ }^{* * *} p<0.0001{ }^{* * *} p<0.001{ }^{* *} p<0.01$

$1211{ }^{*} \mathrm{p}<0.05$.

1212 Figure 6. Identification of overlapping genes in mammary epithelial cells and

1213 mammary tumors overexpressing PTHrP. A) Venn diagram indicating overlap

1214 between differentially expressed genes in PTHrP-overexpressing MECs (purple) and

1215 tumors (green). B) Chord plot illustrating a detailed relationship between the $\log _{2}$-fold

1216 change $\left(\log _{2} \mathrm{FC}\right)$ of overlapped DEGs (left semicircle) and their enriched selected

1217 biological pathways. C) Pathways analysis on differentially expressed overlapped

1218 genes. Bar length represents gene count; bar color represents padj.

1219 Figure 7. Overexpression of PTHrP, but not exogenously added PTHrP, activates

1220 Stat5 in tumor cells. Tet-PTHrP;PyMT tumor cells were treated with Dox $(2 \mu \mathrm{g} / \mathrm{ml})$ or

1221 PTHrP 1-34 (100nM) and protein lysates and RNA was prepared. A) Western blot 
1222 analysis of protein lysates. Left, representative immunoblots of $p$ (Tyr694)Stat5 and total

1223 Stat5 are shown. Right, densitometric quantification of the western blots. N=3. B) QPCR

1224 analysis of the indicated milk proteins. Hprt1 was used as housekeeping gene. $\mathrm{N}=3 \mathrm{C}$ )

1225 Edu incorporation in cultured Tet-PTHrP;PyMT tumor cells in response to Dox or PTHrP

1226 treatment vs control. $\mathrm{N}=9$. Bars represent mean $\pm \mathrm{SEM},{ }^{* \star *} \mathrm{p}<0.0001{ }^{* *} \mathrm{p}<0.01$

$1227{ }^{*} p<0.05$

1228 Figure 8. Knocking down or blocking PTH1R in tumors does not prevent the

1229 effects of PTHrP overexpression in vivo. A) QPCR analysis of PTH1R expression in

1230 RNA from cultured HC11, Tet-PTHrP, PyMT and Tet-PTHrP;PyMT cells. Actb was used

1231 as housekeeping gene. A minimum of $n=3$ per group. B) Kaplan-Meier analysis of tumor

1232 onset (top) and survival (bottom) of Tet-PTHrP;PyMT;PTH1RLox and Tet-

1233 PTHrP;PyMT;Cre;PTH1RLox mice treated with Dox from birth. C) Relative expression

1234 of PTH1R in RNA from isolated tumor cells. $\mathrm{N}=3 . \mathrm{D}) \& \mathrm{H})$ QPCR analysis of indicated

1235 genes. Hprt1 was used as housekeeping gene. N=3. E)\&I) Representative

1236 immunohistochemical staining for nuclear pStat5 in tumor sections from Tet-

1237 PTHrP;PyMT;Cre;PTH1RLox mice treated with Dox and controls and from Tet-

1238 PTHrP;PyMT treated with Dox and an anti-PTH1R antibody (aPTH1R) and controls.

$1239 \mathrm{~N}=3$, Scale bar $100 \mu \mathrm{m}$. F) QPCR analysis of hPTHLH expression in RNA from whole

1240 tumors. Hprt1 was used as housekeeping gene. N=3. G) Serum calcium concentration.

1241 A minimum $n=6$. G) Bars represent mean \pm SEM, ${ }^{* \star *} p<0.0001^{* * *} p<0.001{ }^{* \star} p<0.01$

$1242{ }^{*} p<0.05$

1243 Figure 9. scRNA-seq analysis of PTHLH expression in human breast tumors. A)

1244 Top panel: UMAP of clusters identified by scRNAseq of epithelial cells only $(E \mathrm{ECAM}+)$ 
1245 separated by cancer subtype (ER+ epithelial cells ( $n=65,550)$, HER2+ epithelial cells

$1246(n=22,231)$, and TNBC epithelial cells $(n=16,496))$. Middle and Bottom Panel: UMAP

1247 overlays of PTHLH low and high expressing cells. B) Table containing the proportion of

1248 PTHLH expressing cells in each cancer subtype. C) fGSEA pathway analysis on DEGs

1249 from PTHLH-high vs. PTHLH-low cells using pooled data from all tumor sub-types. 
bioRxiv preprint doi: https://doi.org/10.1101/2021.12.28.473846; this version posted December 28, 2021. The copyright holder for this preprint (which was not certified by peer review) is the author/funder, who has granted bioRxiv a license to display the preprint in perpetuity. It is made available under aCC-BY-NC-ND 4.0 International license.

\section{Figure 1}

A

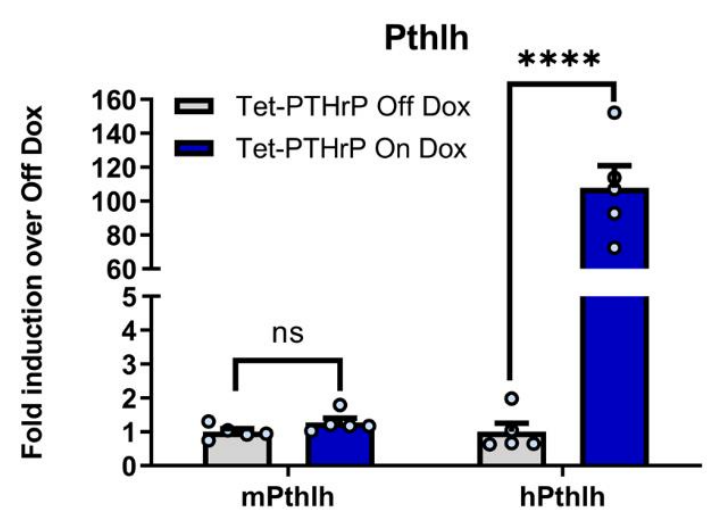

B

\section{MMTV-rtTA on Dox Tet-PTHrP Off Dox Tet-PTHrP on Dox}
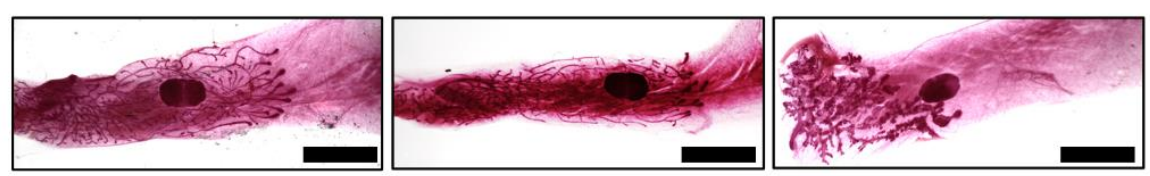

13 wks
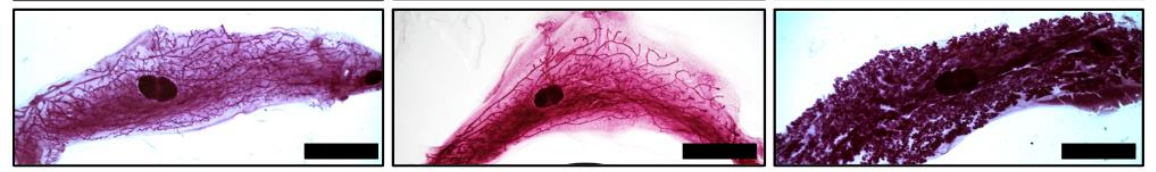

C

H\&E

13 wks
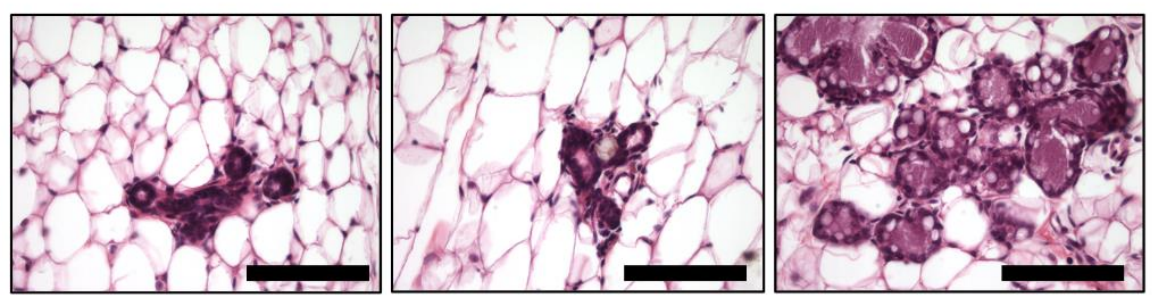

$$
\text { MMTV-rtTA }
$$

Tet-PTHrP

D
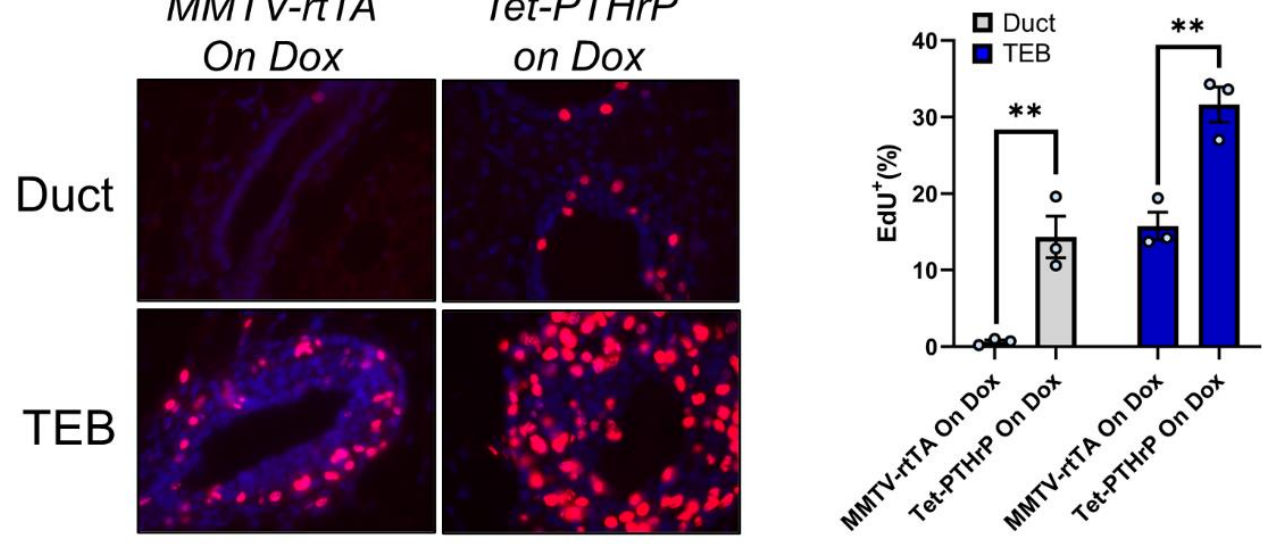
bioRxiv preprint doi: https://doi.org/10.1101/2021.12 28.473846; this version posted December 28, 2021. The copyright holder for this preprint (which was not certified by peer review) is the author/funder, who has granted bioRxiv a license to display the preprint in perpetuity. It is made available under aCC-BY-NC-ND 4.0 International license.

\section{Figure 2}

\section{A}

1255

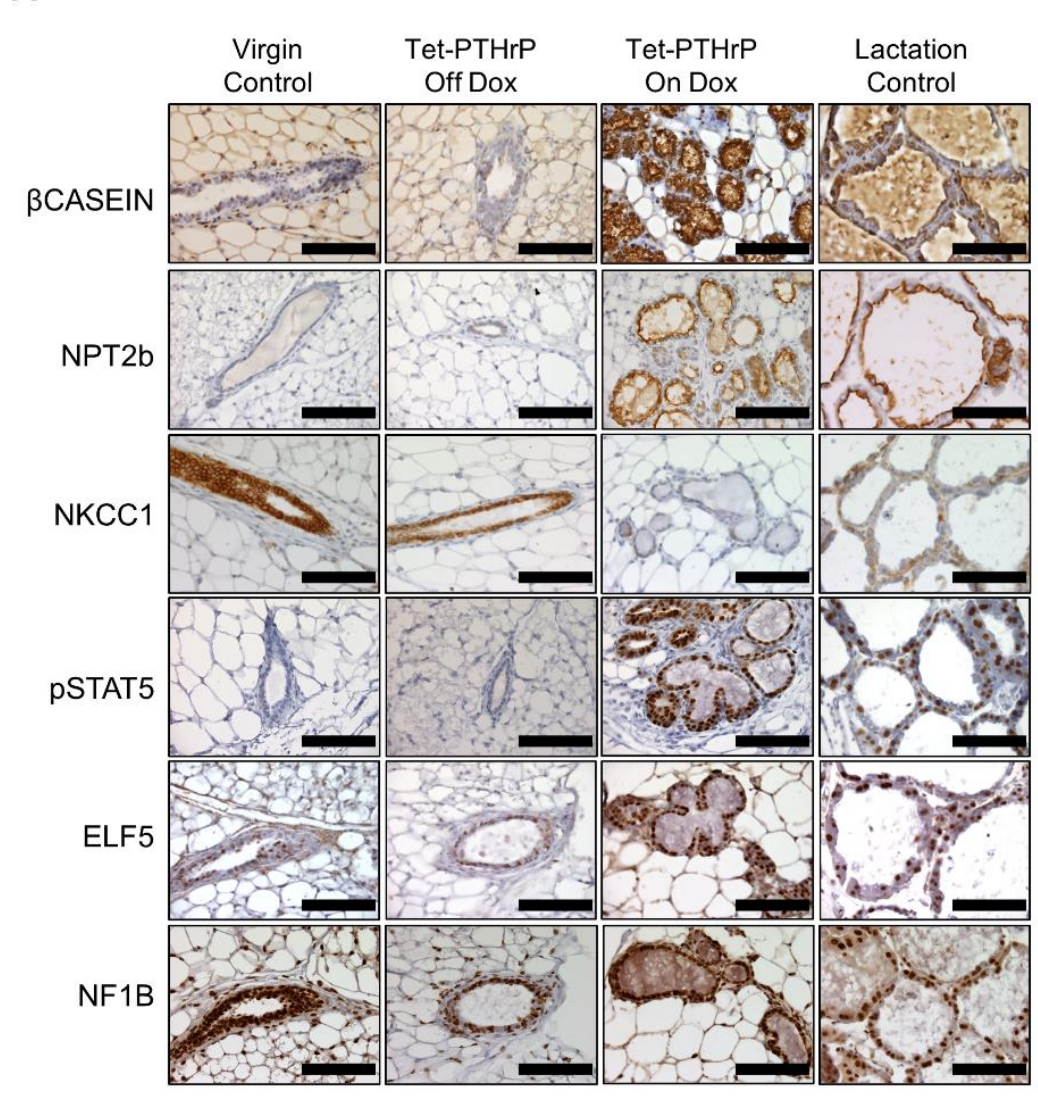

B

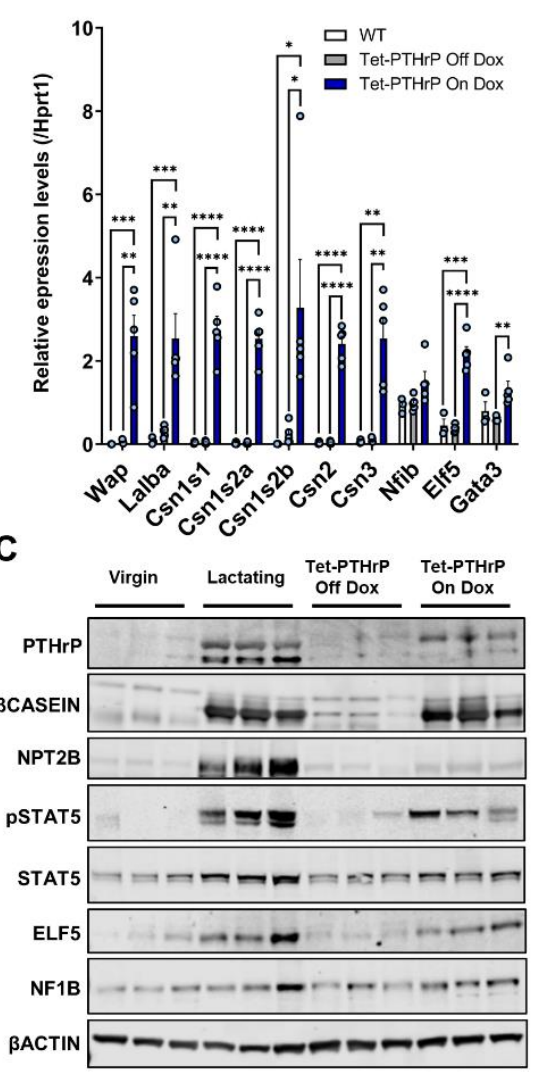


bioRxiv preprint doi: https://doi.org/10.1101/2021.12.28.473846; this version posted December 28, 2021. The copyright holder for this preprint (which was not certified by peer review) is the author/funder, who has granted bioRxiv a license to display the preprint in perpetuity. It is made available under aCC-BY-NC-ND 4.0 International license.

\section{Figure 3}

A

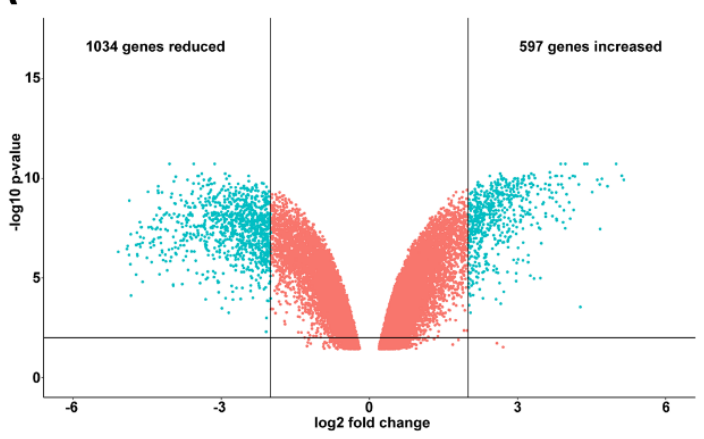

C

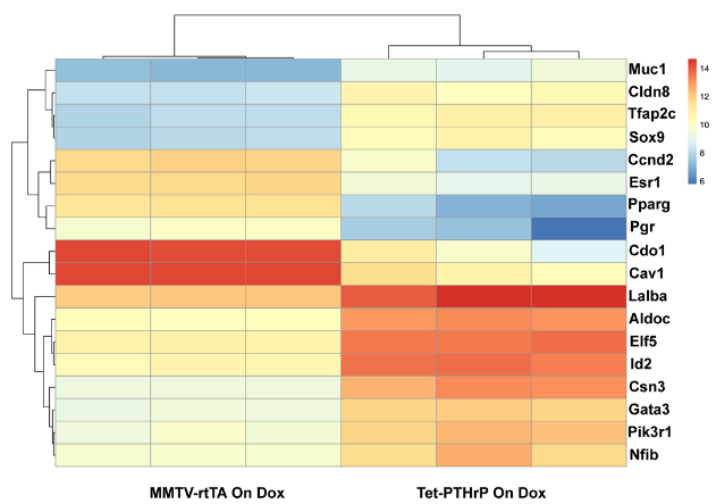

B

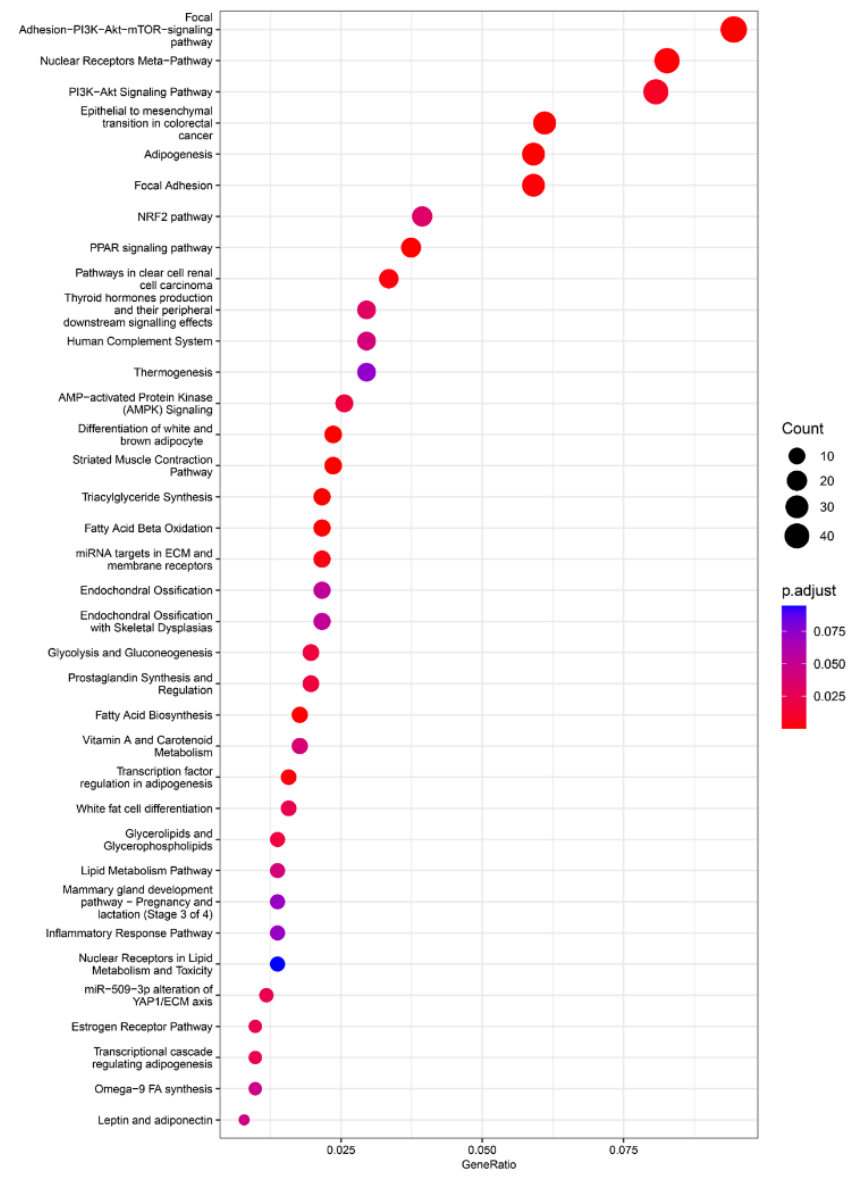


bioRxiv preprint doi: https://doi.org/10.1101/2021.12.28.473846; this version posted December 28, 2021. The copyright holder for this preprint (which was not certified by peer review) is the author/funder, who has granted bioRxiv a license to display the preprint in perpetuity. It is made available under aCC-BY-NC-ND 4.0 International license.

\section{Figure 4}

A

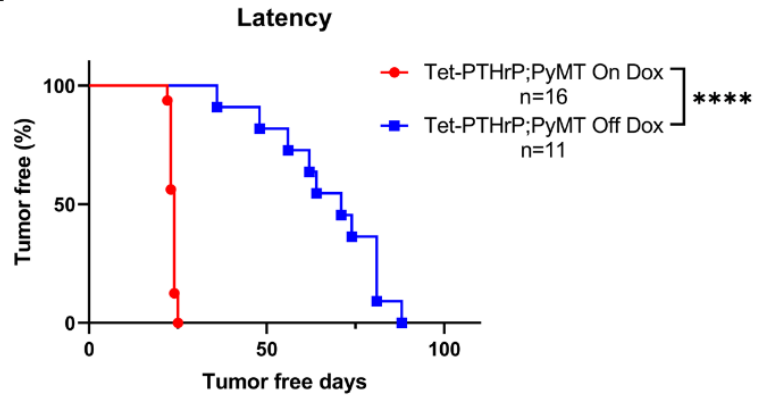

C

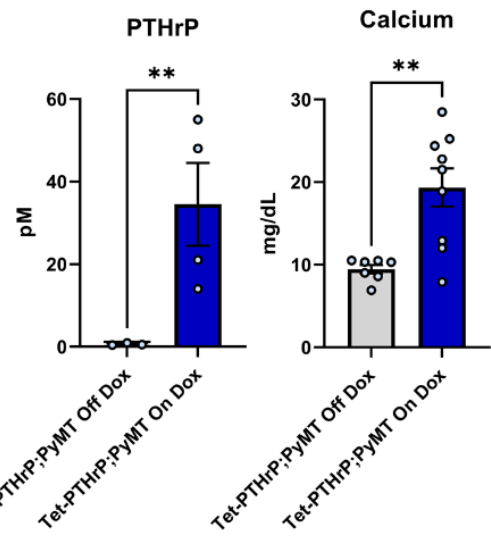

B
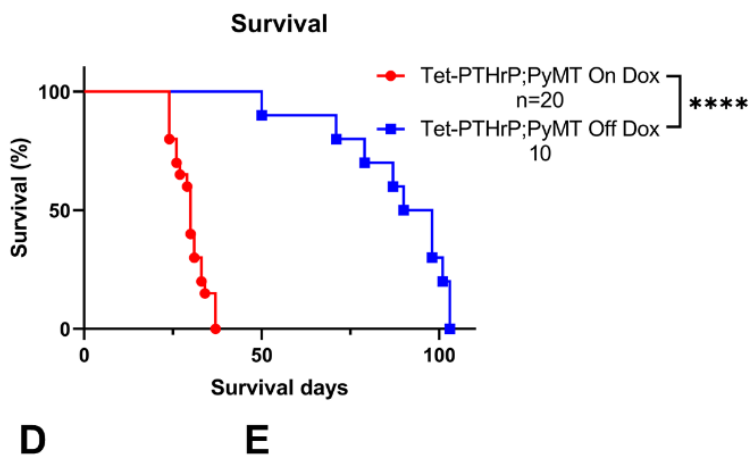

$E$

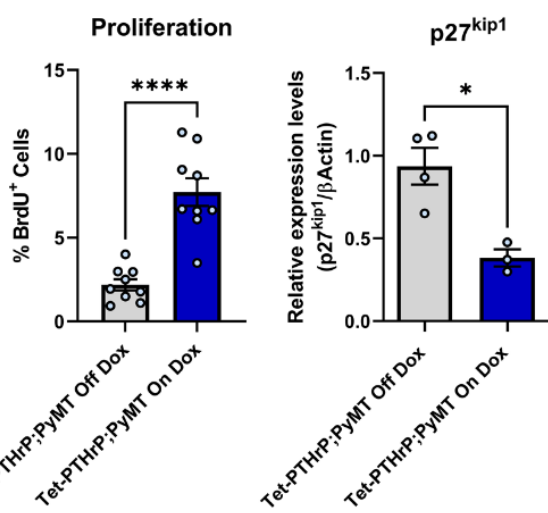


bioRxiv preprint doi: https://doi.org/10.1101/2021.12.28.473846; this version posted December 28, 2021. The copyright holder for this preprint (which was not certified by peer review) is the author/funder, who has granted bioRxiv a license to display the preprint in perpetuity. It is made available under aCC-BY-NC-ND 4.0 International license.

\section{Figure 5}

A

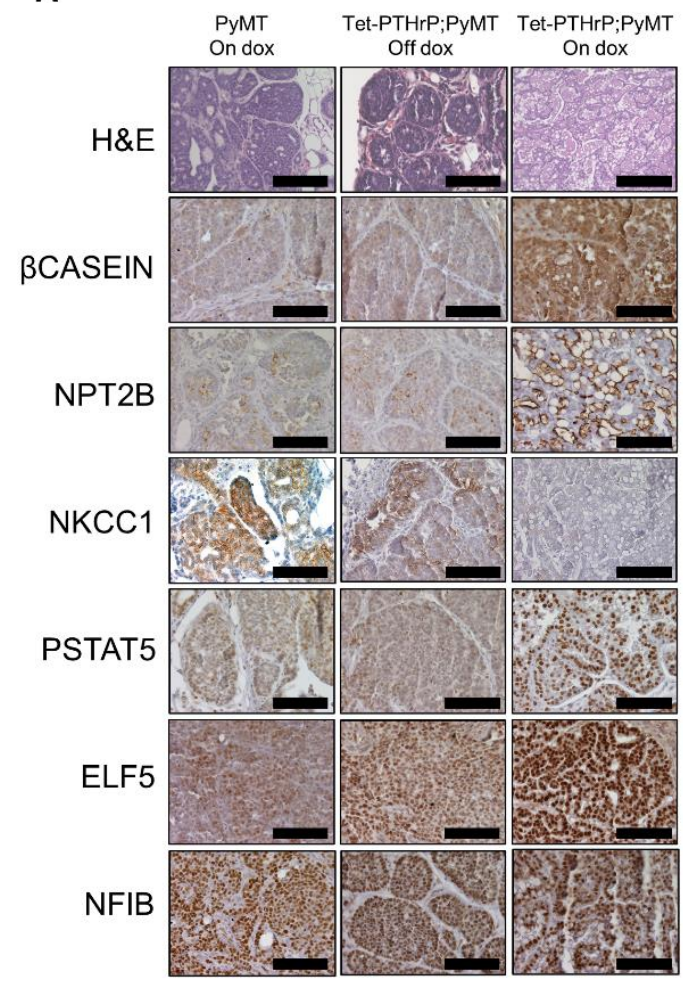

B
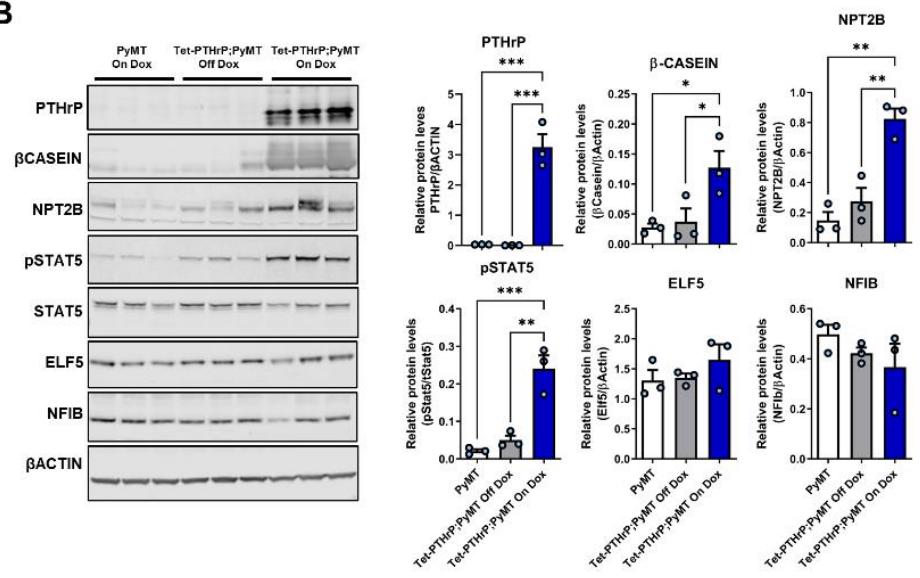

C

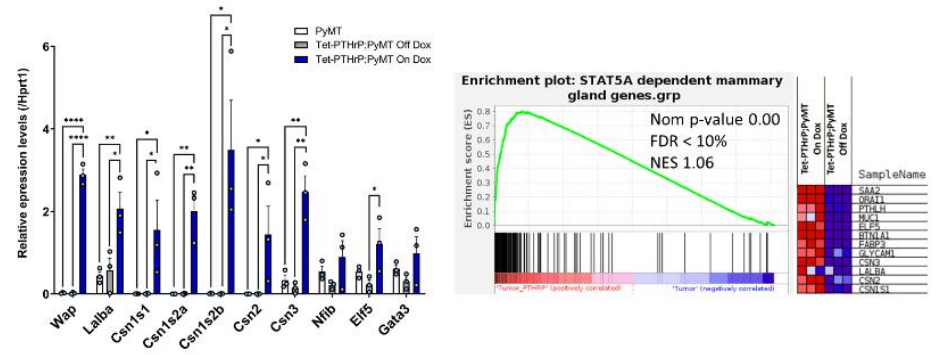


bioRxiv preprint doi: https://doi.org/10.1101/2021.12 28.473846; this version posted December 28, 2021. The copyright holder for this preprint (which was not certified by peer review) is the author/funder, who has granted bioRxiv a license to display the preprint in perpetuity. It is made available under aCC-BY-NC-ND 4.0 International license.

\section{Figure 6}

A

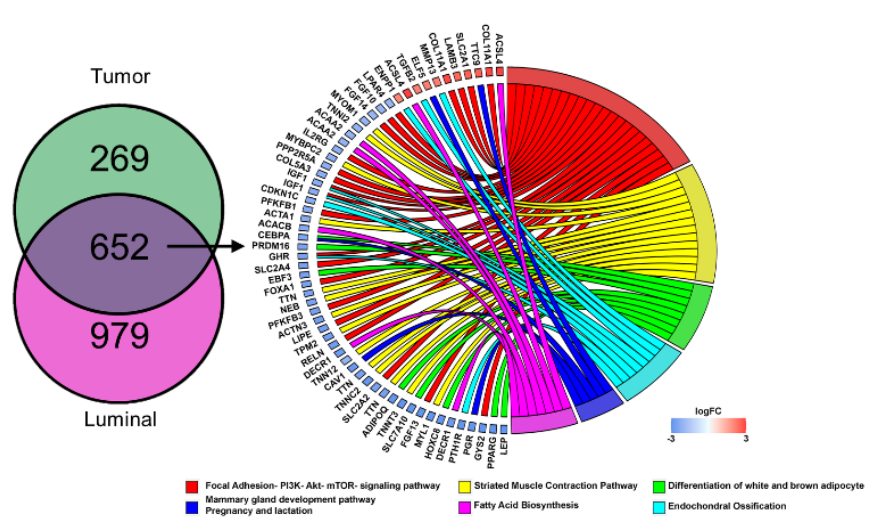

B

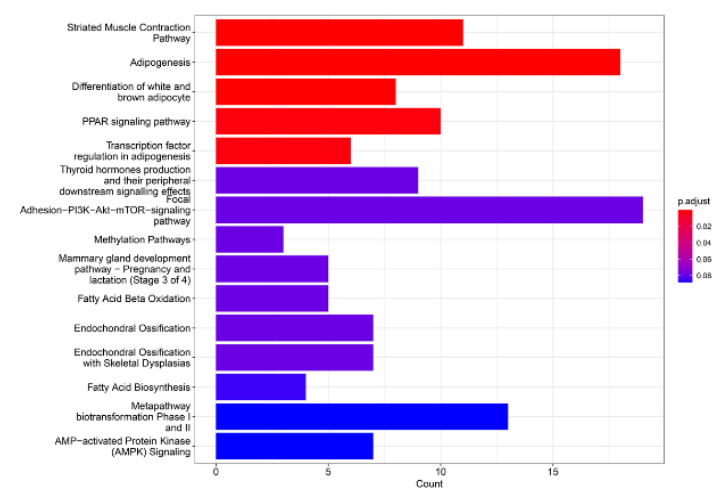


A

Dox $(2 \mu \mathrm{g} / \mathrm{ml})$ Oh $12 \mathrm{~h} 24 \mathrm{~h}$

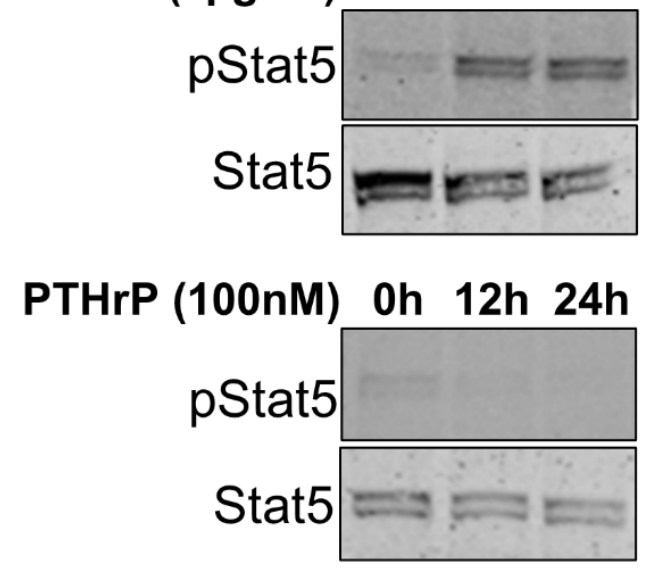

B

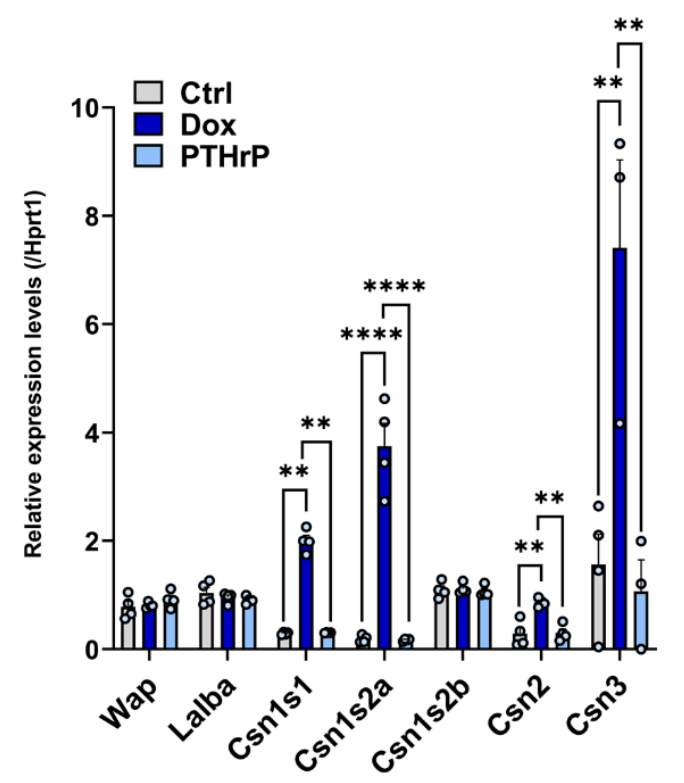

pStat5

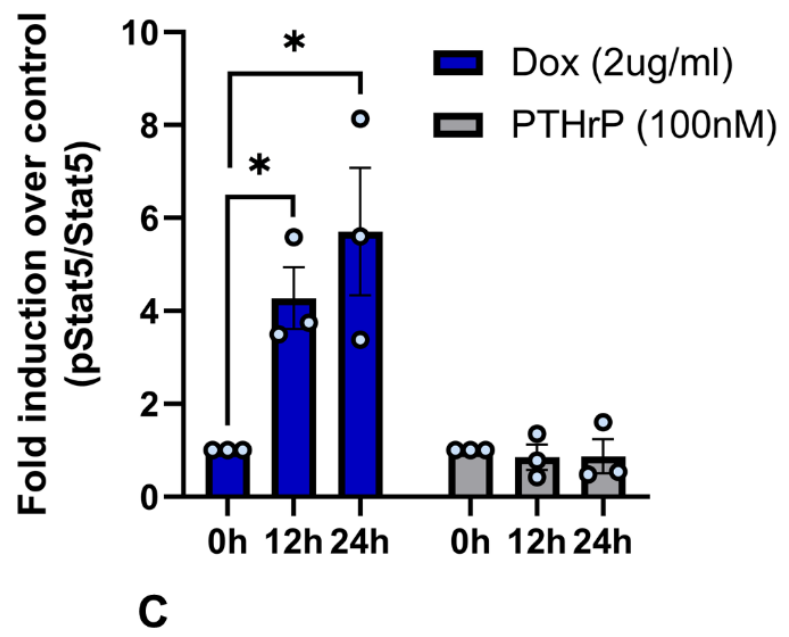

Proliferation

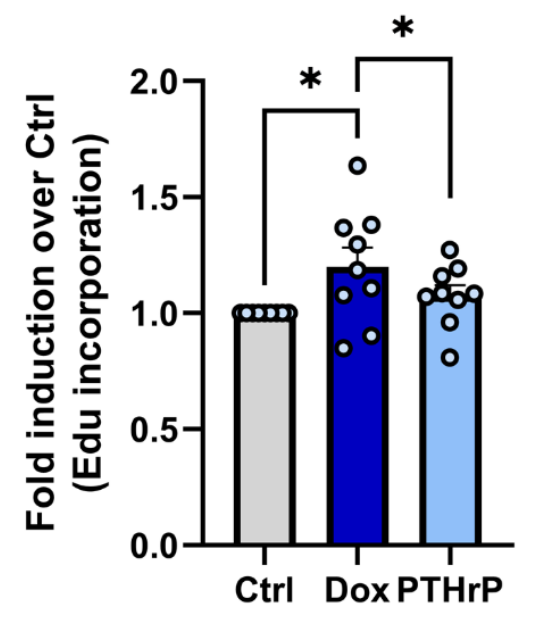


bioRxiv preprint doi: https://doi.org/10.1101/2021.12.28.473846; this version posted December 28, 2021. The copyright holder for this preprint (which was not certified by peer review) is the author/funder, who has granted bioRxiv a license to display the preprint in perpetuity. It is made available under aCC-BY-NC-ND 4.0 International license.

\section{Figure 8}

A

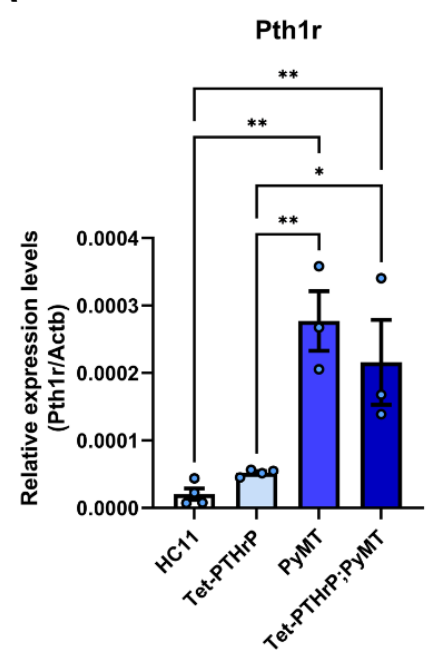

C

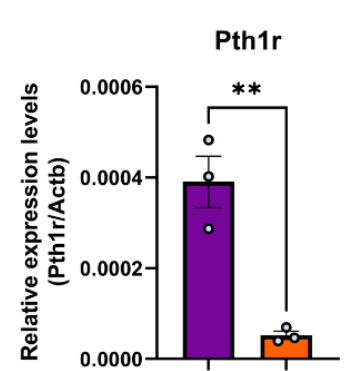

$\mathbf{F}$

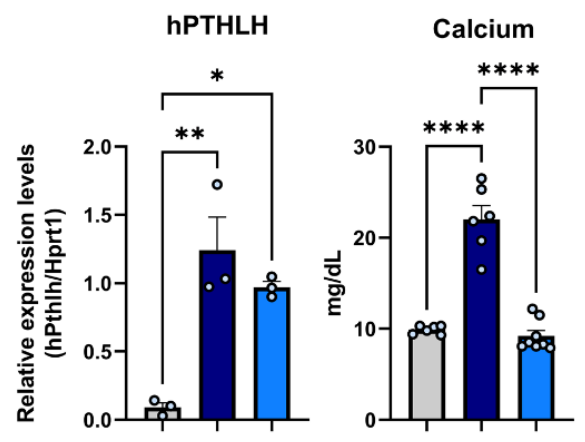

B
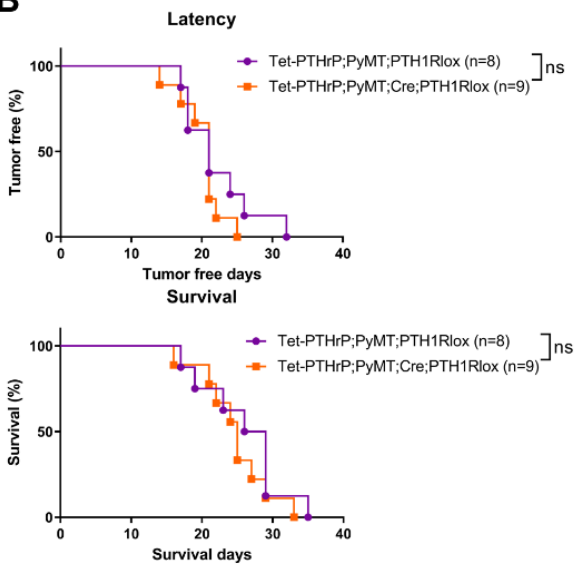

D

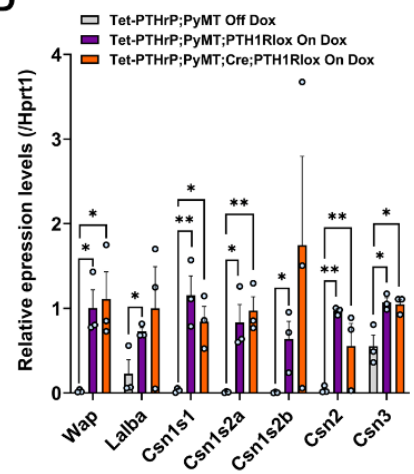

H

믄 Tet-PTHrP;PyMT Off Dox

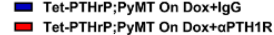

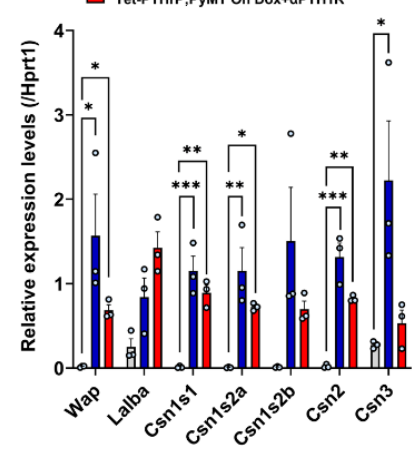

E

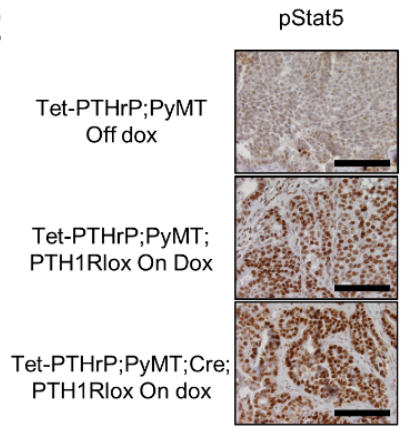

I

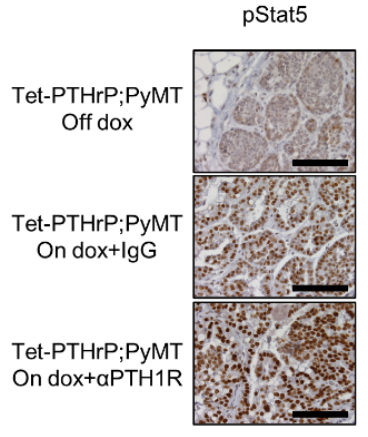

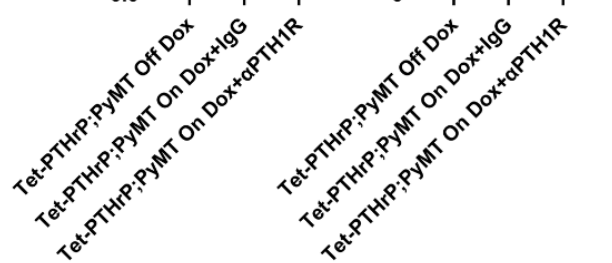


bioRxiv preprint doi: https://doi.org/10.1101/2021.12 28.473846; this version posted December 28, 2021. The copyright holder for this preprint (which was not certified by peer review) is the author/funder, who has granted bioRxiv a license to display the preprint in perpetuity. It is made available under aCC-BY-NC-ND 4.0 International license.

\section{Figure 9}

A
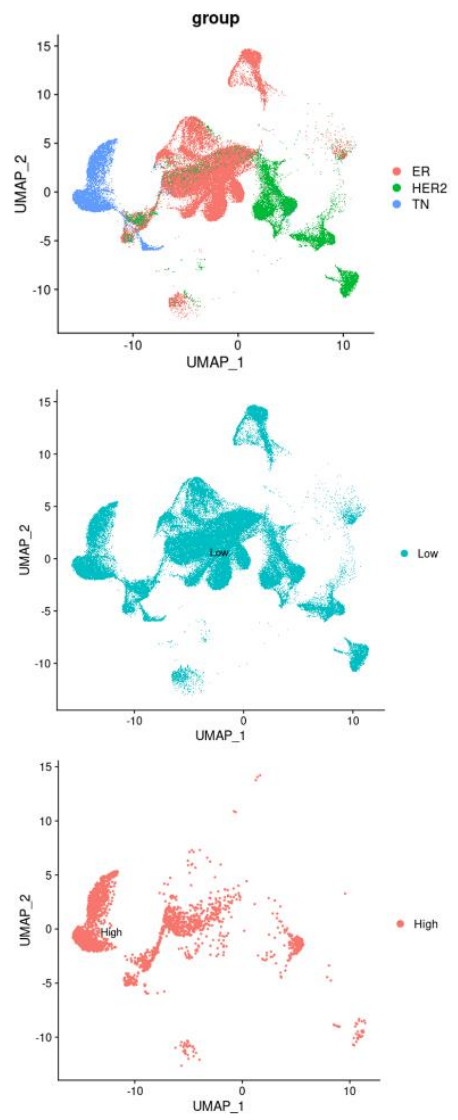

B

\begin{tabular}{|l|c|c|c|c|}
\hline \multicolumn{2}{|c|}{ PTHLH } & ER+ & HER2+ & TNBC \\
\hline \multirow{3}{*}{ Cell number } & High(>0) & 984 & 345 & 1471 \\
\cline { 2 - 5 } & Low(= 0) & 64566 & 21886 & 15025 \\
\hline \multirow{2}{*}{ Fraction (\%) } & Total & 65550 & 22231 & 16496 \\
\cline { 2 - 5 } & High(>0) & 1.50 & 1.55 & 8.92 \\
\hline & Low(= 0) & 98.50 & 98.45 & 91.08 \\
\hline
\end{tabular}

C

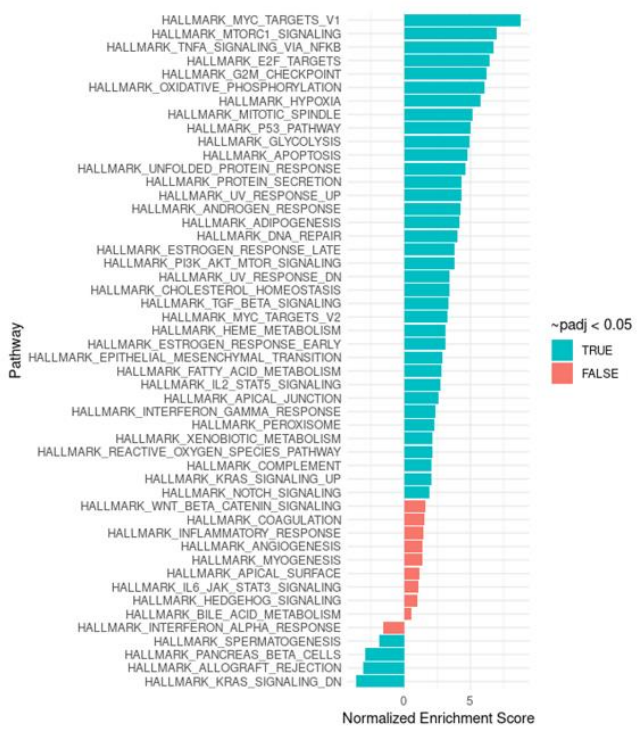

